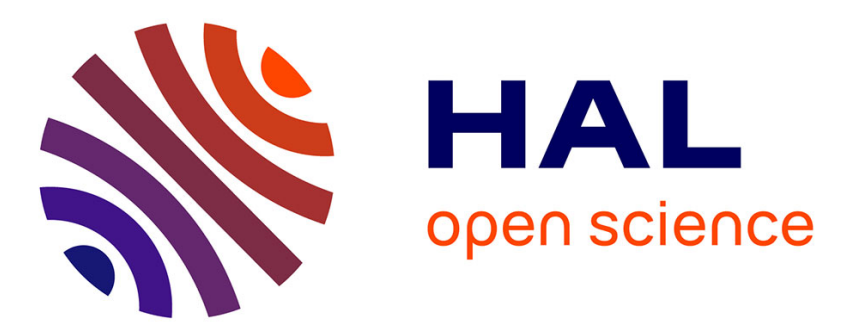

\title{
A LREE-depleted component in the Afar plume: Further evidence from Quaternary Djibouti basalts
}

\author{
Mohammed Daoud, René Maury, Jean-Alix J-A Barrat, R. E. Taylor, Bernard
} Le Gall, Hervé Guillou, Joseph Cotten, Joël Rolet

\section{- To cite this version:}

Mohammed Daoud, René Maury, Jean-Alix J-A Barrat, R. E. Taylor, Bernard Le Gall, et al.. A LREE-depleted component in the Afar plume: Further evidence from Quaternary Djibouti basalts. Lithos, 2010, 114 (3-4), pp.327-336. 10.1016/j.lithos.2009.09.008 . insu-00465553

\section{HAL Id: insu-00465553 \\ https://hal-insu.archives-ouvertes.fr/insu-00465553}

Submitted on 24 Feb 2011

HAL is a multi-disciplinary open access archive for the deposit and dissemination of scientific research documents, whether they are published or not. The documents may come from teaching and research institutions in France or abroad, or from public or private research centers.
L'archive ouverte pluridisciplinaire HAL, est destinée au dépôt et à la diffusion de documents scientifiques de niveau recherche, publiés ou non, émanant des établissements d'enseignement et de recherche français ou étrangers, des laboratoires publics ou privés. 


\section{A LREE-depleted component in the Afar plume: further 2 evidence from Quaternary Djibouti basalts \\ 3 \\ 4}

Mohamed A. Daoud a,b, René C. Maury a*, Jean-Alix Barrat a5, Rex N. Taylor c, Bernard Le Gall a, Hervé Guillou d, Joseph Cotten a, Joël Rolet a 6 7

8

a 9 Université Européenne de Bretagne, Université de Brest; CNRS; UMR 6538 Domaines Océaniques;

10 Institut Universitaire Européen de la Mer, Place N. Copernic, 29280 Plouzané, France.

ь 11 Centre d'Etudes et de Recherches Scientifiques de Djibouti, B.P. 486, Djibouti.

c12 School of Ocean and Earth Science, NOC, University of Southampton, Southampton SO14 3ZH, UK.

d 13 UMR 1572 LSCE/CEA-CNRS, Domaine du CNRS, 12 avenue de la Terrasse, 91118 Gif-sur-Yvette, 14 France.

15

16 * Corresponding author. Tel.: (33)298498708; fax: (33)298498760

17 E-mail address: maury@univ-brest.fr

18

19 Abstract

20

21 Major, trace element and isotopic ( $\mathrm{Sr}, \mathrm{Nd}, \mathrm{Pb}$ ) data and unspiked $\mathrm{K}-\mathrm{Ar}$ ages are presented for Quaternary 22 (0.90-0.95 Ma old) basalts from the Hayyabley volcano, Djibouti. These basalts are LREE-depleted $\left(\mathrm{Lan}_{\mathrm{n}} / \mathrm{Sm}_{\mathrm{n}}=\right.$ 0.76-0.83), with $87 \mathrm{Sr} / 86 \mathrm{Sr}$ ratios ranging from 0.70369 to 0.70376 , and rather homogeneous $143 \mathrm{Nd} / 14423 \mathrm{Nd}(\mathrm{Nd}=$ +5.9 - +7.3) and $\mathrm{Pb}$ isotopic compositions $\left(206 \mathrm{~Pb} / 204 \mathrm{~Pb}=18.47-18.55,{ }_{207} \mathrm{~Pb} / 204 \mathrm{~Pb}=15.52-15.57,{ }_{208} \mathrm{~Pb} / 20424 \mathrm{~Pb}=\right.$ 25 38.62-38.77). They are very different from the underlying enriched Tadjoura Gulf basalts, and from the N26 MORB erupted from the nascent oceanic ridges of the Red Sea and Gulf of Aden. Their compositions closely 27 resemble those of (1) depleted Quaternary Manda Hararo basalts from the Afar depression in Ethiopia and (2)

28 one Oligocene basalt from the Ethiopian Plateau trap series. Their trace element and Sr, $\mathrm{Nd}, \mathrm{Pb}$ isotope 29 systematics suggest the involvement of a discrete but minor LREE-depleted component, which is probably an 30 intrinsic part of the Afar plume.

31

\section{1. Introduction.}

34 The study of basalts from intra-oceanic islands and plateaus as well as from traps and 35 rifts has shown the considerable chemical heterogeneity of plume materials (Hart, 1988). This 
heterogeneity might indicate very complex plume structures and dynamics (Lin and van Keken, 2006). However, it may not only result from the initial chemical heterogeneity of mantle plumes at depth but also from the entrainment of surrounding mantle materials (Hart et al., 1992; Furman et al., 2006). In addition, a lithospheric component is clearly recognized in some intracontinental basalts, e.g. in the Afar province, but its origin is still debated (Rogers, 2006). Some authors have suggested that melting of the Afar lithospheric mantle explains a significant proportion of the erupted lavas (Hart et al., 1989; Vidal et al., 1991; Deniel et al., 1994) whilst others point out that continental crust contamination can also contribute to the isotopic signature of these basalts (Barrat et al., 1993; Baker et al., 1996; Pik et al., 1999).

The vast majority of plume-related basalts, including the Afar ones (Furman et al., 2006; Beccaluva et al., 2009) are dominated by a component that is chemically and isotopically enriched. However, the occurrence of subordinate components characterized by a light rare earth element (LREE) depletion has been suggested from the study of basalts from major mantle plumes in: (1) Iceland (Zindler et al., 1979; Hémond et al., 1993; Taylor et al., 1997; Chauvel and Hémond, 2000; Skovgaard et al., 2001; Fitton et al., 2003; Thirlwall et al., 2004; Kokfelt et al., 2006); (2) Hawaii (Chen and Frey, 1985; Yang et al., 2003; Frey et al., 2005); (3) the Galapagos (White et al., 1993; Hoernle et al., 2000; Blichert-Toft and White, 2001; Saal et al., 2007); and (4) the Kerguelen Archipelago (Doucet et al., 2002). However, the characterization of this reservoir is difficult because its signature may be overprinted by either the dominant enriched plume component or the lithospheric reservoirs. Therefore, the presence of an intrinsic depleted component in plumes is still an open question.

LREE-depleted basalts associated to the Afar mantle plume have long been recognized in the Quaternary Manda Hararo volcanic chain, Ethiopia (Treuil and Joron, 1975; Joron et al., 1980; Barrat et al., 2003). A single LREE-depleted Oligocene Ethiopian Plateau basalt has also been so far analysed (sample E88: Pik et al., 1998, 1999). The purpose of this paper is: (1) to describe another newly discovered occurrence of such basalts in the SE part of the Afar triangle, i.e. the rather large Hayyabley Quaternary volcano in Djibouti (Fig. 1), and (2) to discuss its bearing on the composition and heterogeneity of the Afar mantle plume.

\section{Analytical techniques}

Ar isotopic compositions and $\mathrm{K}$ contents (Table 1) were measured at Gif-sur-Yvette and IUEM (Institut Universitaire Européen de la Mer), respectively. The samples were crushed, sieved to $0.25-0.125 \mathrm{~mm}$ size fraction and ultrasonically washed in acetic acid. Potassium and 
argon were measured on the microcrystalline groundmass, after removal of phenocrysts using heavy liquids of appropriate densities and magnetic separations. This process improves the $\mathrm{K}$ yield as well as the percentage of radiogenic argon, and removes at least some potential sources of systematic error due to the presence of excess ${ }^{40} \mathrm{Ar}$ in olivine and feldspar phenocrysts (Laughlin et al., 1994). Ar analyses were performed using the procedures detailed in Yurtmen et al. (2002) and Guillou et al. (2004). The unspiked technique differs from the conventional isotope dilution method in that argon extracted from the sample is measured in sequence with purified aliquots of atmospheric argon at the same working gas pressure in the mass-spectrometer. This suppresses mass discrimination effects between the atmospheric reference and the unknown, and allows quantities of radiogenic ${ }^{40} \mathrm{Ar}^{*}$ as small as $0.14 \%$ to be detected on a single-run basis (Scaillet et al., 2004). Argon was extracted by radio frequency heating of $2.0-3.0 \mathrm{~g}$ of sample, then transferred to an ultra-high-vacuum glass line and purified with titanium sponge and $\mathrm{Zr}$-Ar getters. Isotopic analyses were performed on total ${ }^{40} \mathrm{Ar}$ contents ranging between 2.4 and $3.2 \times 10^{-11}$ moles using a $180^{\circ}, 6 \mathrm{~cm}$ radius mass spectrometer with an accelerating potential of $620 \mathrm{~V}$. The manometric calibration (Charbit et al.,1998) was based on periodic, replicate determinations of international dating standards including LP-6 (Odin et al., 1982) and HD-B1 (Fuhrmann et al., 1987). The total ${ }^{40} \mathrm{Ar}$ content of the sample can be determined with a precision of $\pm 0.2 \%(2 \sigma)$ according to this procedure. Ages were calculated using the constants recommended by Steiger and Jäger (1977).

Major element compositions of minerals and glasses were determined using a Cameca SX50 five spectrometer automated electron microprobe (Microsonde Ouest, Plouzané, France). Analytical conditions were $15 \mathrm{kV}, 10-12 \mathrm{nA}$ and a counting time of 6 sec. (see Defant et al., 1991, for further analytical details). Major and trace element data on bulk rocks (Table 2) were first obtained by Inductively Coupled Plasma-Atomic Emission Spectrometry (ICP-AES) at IUEM, Plouzané. The samples were finely powdered in an agate grinder. International standards were used for calibration tests (ACE, BEN, JB-2, PM-S and WS-E). $\mathrm{Rb}$ was measured by flame emission spectroscopy. Relative standard deviations are $\pm 1 \%$ for $\mathrm{SiO}_{2}$, and $\pm 2 \%$ for other major elements except $\mathrm{P}_{2} \mathrm{O}_{5}$ and $\mathrm{MnO}$ (absolute precision $\pm 0.01 \%$ ), and ca. 5\% for trace elements. The analytical techniques are described in Cotten et al. (1995). Concentrations of additional trace elements were measured by Inductively Coupled Plasma Mass Spectrometry (ICP-MS) at IUEM, using a Thermo Element 2 spectrometer following procedures adapted from Barrat et al. (1996, 2000). Based on standard measurements and sample duplicates, trace element concentration reproducibility is generally better than $5 \%$ (Barrat et al., 2007), and are in good agreement with the ICP-AES results (Table 2). 
Isotopic compositions of $\mathrm{Sr}$ and $\mathrm{Nd}$ (Table 4) were determined at IUEM. Conventional ion exchange techniques were used for separation of $\mathrm{Sr}$, and isotope ratio measurements were carried out by thermal ionization mass spectrometry using a Thermo Triton equipped with 7 collectors. Isotopic ratios were normalized for instrumental mass fractionation relative to ${ }^{86} \mathrm{Sr} /{ }^{88} \mathrm{Sr}=0.1194 .{ }^{87} \mathrm{Sr} /{ }^{86} \mathrm{Sr}$ of the NBS $987 \mathrm{Sr}$ standard yielded $0.710213 \pm 22(2 \sigma, \mathrm{n}=14)$ and the sample $\mathrm{Sr}$ isotopic compositions are reported relative to ${ }^{87} \mathrm{Sr} /{ }^{86} \mathrm{Sr}=0.71024$. The $\mathrm{Nd}$ purification was done according to the procedure described in Dosso et al. (1993). TRU Spec chromatographic resins from Eichrom were used to separate the REE fraction from the sample matrix. Then, the separation and elution of $\mathrm{Nd}$ and other REE were realized on Ln.Spec resin. During the course of the study, analyses of the La Jolla standard were performed and gave an average of ${ }^{143} \mathrm{Nd} /{ }^{144} \mathrm{Nd}=0.511845 \pm 6(\mathrm{n}=15)$. All $\mathrm{Nd}$ data were fractionation-corrected to ${ }^{146} \mathrm{Nd} /{ }^{144} \mathrm{Nd}=0.7219$ and further normalized to a value of ${ }^{143} \mathrm{Nd} /{ }^{144} \mathrm{Nd}=0.511860$ for the $\mathrm{La}$ Jolla standard.

Isotopic compositions of $\mathrm{Pb}$ were determined at the National Oceanography Centre, Southampton, using the SBL 74 double spike. Powdered samples were leached with $6 \mathrm{M} \mathrm{HCl}$ at $140^{\circ} \mathrm{C}$ for 1 hour and then rinsed up to 6 times with ultrapure water prior to dissolution. Lead separation was then performed on an anionic exchange resin. High-resolution $\mathrm{Pb}$ isotopic analyses were carried out on a VG sector 54 multi-collector instrument, using the double spike technique with the calibrated Southampton-Brest ${ }^{207} \mathrm{~Pb} /{ }^{204} \mathrm{~Pb}$ spike (Ishizuka et al., 2003). The true $\mathrm{Pb}$ isotopic compositions were obtained from the natural and mixture runs by iterative calculation adopting a modified linear mass bias correction (Johnson and Beard, 1999). The reproducibility of this Pb isotopic measurement (external error: $2 \sigma$ ) by double spike is $<200 \mathrm{ppm}$ for all ${ }^{20 x} \mathrm{~Pb} /{ }^{204} \mathrm{~Pb}$ ratios. Measured values for NBS SRM-981 during the measurement period were ${ }^{206} \mathrm{~Pb} /{ }^{204} \mathrm{~Pb}=16.9414 \pm 26, \quad{ }^{207} \mathrm{~Pb} /{ }^{204} \mathrm{~Pb}=15.4997 \pm 30$ and ${ }^{208} \mathrm{~Pb} /{ }^{204} \mathrm{~Pb}=36.726 \pm 9(2 \sigma, n=9) . \mathrm{Pb}$ blanks measured using this procedure were $<100 \mathrm{pg}$, and thus negligible relative to the amount of sample analysed.

\section{Geological setting and K-Ar ages}

\subsection{Geological and tectonic framework}

The geology of the Republic of Djibouti records the effects of the activity of the Afar mantle plume since 30 Ma (Schilling, 1973; Barberi et al., 1975; Barberi and Varet, 1977; 
138 Furman et al., 2006). Plume-related basaltic and derived magmas, variably enriched in incompatible elements (e.g., Joron et al., 1980; Deniel et al., 1994) cover ca. 90\% of its surface, and range in age from at least $23.6 \pm 0.5 \mathrm{Ma}$ to Present (Barberi et al., 1975;

141 Courtillot et al., 1984; Zumbo et al., 1995). Since the Miocene, the most salient tectonomagmatic process observed in the area was the penetration of the Gulf of Aden (GA) oceanic ridge between the Arabia and Somalia plates, hence leading to the opening of the Tadjoura Gulf (Courtillot et al., 1980; Manighetti et al., 1997), at the southwestern edge of which the emerged Asal Rift shows spectacular evidence for both tectonic and magmatic activities (Stieltjes et al., 1976; Needham et al., 1976).

Onland, the principal marker of the Pliocene opening of the Tadjoura Gulf (TG) was the emplacement of a $<350 \mathrm{~m}$-thick basaltic lava flow pile, referred to as the "initial basaltic series from the borders of the Tadjoura Gulf" (Fournier et al., 1982; Gasse et al., 1983), which will be named hereafter the Tadjoura Gulf Basalts (TGB). These very fluid subaerial lava flows are generally assumed to have been emitted from now submerged fissures in the Gulf, and emplaced rather symmetrically outwards on the twin margins (Fig. 1, inset) (Richard, 1979). Additional feeder dykes, and associated neck-like features, have been identified onshore, along the northern flank in the Tadjoura area. TGB range from olivine tholeiites to ferrobasalts, and in thin section are subaphyric to sparsely phyric, with 3-6 modal\% calcic plagioclase, and 1-3 modal\% olivine set in a microlitic groundmass. They display mild, but significant, enrichments in light rare earth elements (LREE) and other highly incompatible elements (Joron et al., 1980; Barrat et al., 1990, 1993; Deniel et al., 1994).

In the Djibouti plain, the TGB are involved in a coastal network of Gulf-parallel tilted fault blocks, bounded by dominantly extensional $\mathrm{N}$-facing structures, in association with $\mathrm{N} 140^{\circ} \mathrm{E}$ normal faults outlined by a swarm of small cinder cones (Fig. 1). To the East, they are post-dated by the Hayyabley elongated volcano, the long axis of which also strikes NWSE, parallel to the regional fault scarp bounding the eastern coastal plain further SE.

\subsection{The Hayyabley volcano}

The youngest volcanic units in the Djibouti plain are a set of generally small (less than $100 \mathrm{~m}$ high) ash and cinder strombolian-type cones with associated basaltic flows (e.g. the Nagâd volcano, Fig. 1), aligned along a young NNW-SSE fracture network (Fournier et al., 1982). They overlie the TGB and have been dated to 1.75-1.70 Ma (Gasse et al., 1983). The largest of these post-TGB volcanic centers is the Hayyabley volcano, east of Djibouti town 
172 (Fig. 1). Although it was shown on the 1:50 000 geological map of Djibouti (Fournier et al., 173 1982), and further well-described and dated by Gasse et al. (1983), it was apparently never

174

175

176

177

178

179

180

181

182

183

184

185

186

187

188

189

190

191

192

193

194

195

196

197

198

199

200

201

202

203

investigated later despite the obviously unusual characteristics of its basaltic lavas.

The Hayyabley volcano in map-view is a $5 \times 10 \mathrm{~km}$ elliptic edifice, with a NNW-SSE trending axis. It has a shield-like and rather flat morphology, and culminates at $147 \mathrm{~m}$ at Signal Bouêt. It overlies the TGB lava flows outcropping W and N of Wadi Ambouli valley (Fig. 1), and seals the EW to WNW-ESE normal fault pattern related to the Tadjoura rift. Despite the rather large aerial extent of its lavas, we estimate its volume to ca. $0.6-0.8 \mathrm{~km}^{3}$ only. Its eruptive vents are no longer identifiable, possibly because of the strong anthropic imprint and constructions of the Djibouti suburbs: they are thought to be located in its summit zone, and aerial photograph data suggest radial emplacement of the lava flows away from this summit (Fournier et al., 1982).

The total thickness of the Hayyabley lava flow pile is estimated at $120 \mathrm{~m}$. The best section is exposed in Wadi Warabor, along the northern coast (Fig. 1). There, we sampled seven superimposed basaltic lava flows (DJ54B to DJ54H), resting conformably upon a 15 mthick columnar-jointed lava flow (DJ54A) belonging to the TGB sequence. These flows are vesicle-rich, and their thickness decreases upwards from ca. $4 \mathrm{~m}$ to less than $20 \mathrm{~cm}$. Only the thickest lava flows show columnar jointing, and the uppermost ones are highly vesicular and often scoriaceous (Gasse et al., 1983). A sample (TF 914) collected from a possible eruption vent in the summit area had been dated by the K-Ar unspiked method to $0.98 \pm 0.10 \mathrm{Ma}$ and $0.83 \pm 0.08 \mathrm{Ma}$ (Gasse et al., 1983), the youngest K-Ar dates obtained so far in the area. We have checked the previous results by dating two basaltic flows from the Wadi Warabor section (Fig. 1). The results are shown in Table 1. The two ages obtained, $0.93 \pm 0.06 \mathrm{Ma}$ and $1.06 \pm 0.09 \mathrm{Ma}$, are mutually consistent, and compatible as well with those previously published (Gasse et al., 1983). Indeed, the four results almost overlap at around $0.91-0.97$ $\mathrm{Ma}$, and are remarkably convergent considering the very low concentration of potassium in the studied samples and the young age range.

\section{Petrologic and geochemical results}

\subsection{Petrographic and mineralogical features}


The Hayyabley basalts are rather homogeneous from a petrographic point of view, and also quite different from the underlying TGB. They are moderately to highly vesicular (10 to 30 modal\% vesicles in thin section). These vesicles are usually empty, or sometimes partly filled by calcite, especially in the summit part of the volcano. The rocks are also sparsely to moderately phyric, with 5 to 15 modal\% phenocrysts, the size of which ranges from 0.5 to 3 $\mathrm{mm}$. They include olivine (dominant) and calcic plagioclase (subordinate), in a roughly 2:1 ratio. These phenocrysts are set in a holocrystalline groundmass, showing doleritic or intersertal textures. It contains, by order of decreasing abundance, plagioclase laths, olivine microcrysts (the periphery of which is often replaced by iddingsite), calcic pyroxene grains and titanomagnetite.

Olivine compositions range from $\mathrm{Fo}_{84-82}$ for the phenocryst cores to $\mathrm{Fo}_{78-54}$ for their rims and the microcrysts, the smallest ones being the most Fe-rich. The plagioclase phenocryst cores are bytownitic $\left(\mathrm{An}_{86-77}\right)$ and contain negligible amounts of Or component $(<0.3 \%)$. The corresponding rims are less calcic $\left(\mathrm{An}_{70-32}\right)$ and the small laths from the groundmass are clearly enriched in alkalis (up to $\mathrm{An}_{27-15} \mathrm{Ab}_{70-80} \mathrm{Or}_{2-5}$ ). Groundmass clinopyroxenes are augitic $\left(\mathrm{Wo}_{45-41} \mathrm{En}_{43-40} \mathrm{Fs}_{12-16}\right)$ and their low $\mathrm{TiO}_{2}(<1 \mathrm{wt} \%)$ and $\mathrm{Na}_{2} \mathrm{O}(<0.3 \mathrm{wt} \%)$ contents are typical of tholeiitic clinopyroxenes.

\subsection{Major and trace elements on bulk rocks}

Nine samples taken from different flows from four locations (Fig. 1) were analysed, and the results are given in Table 2. Their major and trace element abundances are rather uniform. These lavas display high $\mathrm{Al}_{2} \mathrm{O}_{3}(16.4-17.05 \mathrm{wt} \%)$ and $\mathrm{CaO}$ (12.5-13.8 wt\%) abundances, low $\mathrm{Na}_{2} \mathrm{O}(1.9-2.1 \mathrm{wt} \%$ ) abundances and $\mathrm{FeO} * / \mathrm{MgO}$ ratios close to 1 . Although not primitive, these lavas are amongst the least evolved basalts collected so far from the Republic of Djibouti. Indeed, they exhibit the highest compatible trace element abundances (e.g., Ni, Co, Cr) measured in samples from this area (e.g., Joron et al., 1980; Barrat et al., 1990, 1993; Deniel et al., 1994).

More importantly, their incompatible trace element abundances are low, and these samples are characterized by light REE depletions $\left(\mathrm{La}_{\mathrm{n}} / \mathrm{Sm}_{\mathrm{n}}=0.76-0.83\right)$, and small but significant positive $\mathrm{Eu}$ anomalies $\left(\mathrm{Eu} / \mathrm{Eu}^{*}=1.08-1.12\right.$, Fig. 2). These features unambiguously distinguish the Hayyabley basalts from both the TGB and the older post-TGB basalts, which are always LREE-enriched (Joron et al., 1980; Barrat et al., 1990, 1993; Deniel et al., 1994). 
The unusual features of the Hayyabley basalts are strengthened by their primitive mantle normalised patterns that exhibit large positive $\mathrm{Ba}\left(\mathrm{Ba}_{\mathrm{n}} / \mathrm{Rb}_{\mathrm{n}}=2.9-8.6\right)$ and $\mathrm{Sr}\left(\mathrm{Sr}_{\mathrm{n}} / \mathrm{Ce}_{\mathrm{n}}=1.8-2.1\right)$ anomalies (Fig. 3). Although LREE-depleted, the Hayyabley basalts are clearly distinct from typical N-MORB and basalts erupted by the nearby nascent oceanic ridges. For example, basalts with $\mathrm{N}$ to T-MORB affinities are known from the eastern part of the Tadjoura Gulf (Barrat et al., 1990, 1993). Although a positive Sr anomaly has been observed in a single LREE-depleted basalt, positive $\mathrm{Ba}$ and Eu anomalies are missing (Barrat et al., 1990, 1993 and unpublished results). In addition, the $\mathrm{Nb} / \mathrm{Y}$ and $\mathrm{Zr} / \mathrm{Y}$ ratios (0.11-0.15 and 2.20-2.57, respectively, Table 2) of Hayyabley basalts are such that these lavas plot within the field of Icelandic plume basalts, and well above the N-MORB field, in Fitton et al.'s $(1997,2003)$ rectangular plot (not shown).

Interestingly, the Hayyabley basalts are remarkably similar to the scarce LREE-depleted basalts which were sporadically emitted by the Manda Hararo rift, Ethiopia (Barrat et al., 2003). Indeed, the latter display incompatible element abundances and distributions very similar to those of the Hayyabley basalts (Fig. 3). The noticeable differences are minor. The Manda Hararo basalts are somewhat more evolved than the Hayyabley basalts and have for example lower $\mathrm{Ni}$ and $\mathrm{Cr}$ concentrations (Table 3). In addition, an Oligocene basaltic flow with the same features (sample E88) was reported by Pik et al. (1999) from the Ethiopian Plateau.

\section{3. $\mathrm{Sr}, \mathrm{Nd}, \mathrm{Pb}$ isotopic data}

The isotopic compositions of five samples are given in Table 4, and are almost uniform, with the exception of ${ }^{87} \mathrm{Sr} /{ }^{86} \mathrm{Sr}$ ratios which vary significantly in the range $0.70369-0.70396$

262 (Table 4). Although relatively fresh, the Hayyabley basalts display some evidence of weathering. One may suspect that their ${ }^{87} \mathrm{Sr} /{ }^{86} \mathrm{Sr}$ ratios are not pristine, and have been affected by secondary processes. Indeed, the least radiogenic sample DJ59 displays a negative Loss On Ignition (LOI) value (-0.38 wt\%). Conversely, the LOI value of the most radiogenic sample (DJ54H) is much higher $(0.92 \mathrm{wt} \%)$, and in a ${ }^{87} \mathrm{Sr} /{ }^{86} \mathrm{Sr}$ vs. LOI plot (not shown), a weak positive correlation is apparent. In order to check if the $\mathrm{Sr}$ isotopic compositions of the samples were modified by alteration, $150 \mathrm{mg}$ of sample DJ54B was leached for 2 hours in hot $\left(150^{\circ} \mathrm{C}\right) 6 \mathrm{~N} \mathrm{HCl}$, and rinsed in deionized water prior to dissolution. Its ${ }^{87} \mathrm{Sr} /{ }^{86} \mathrm{Sr}$ ratio is significantly lower than the value obtained on the unleached powder (Table 4), a result which 
suggests that the Sr isotopic compositions have been modified by secondary processes.

272 Similar observations were made by Deniel et al. (1994) on other samples from Djibouti. Thus,

$273{ }^{87} \mathrm{Sr} /{ }^{86} \mathrm{Sr}$ obtained on unleached samples from this area should be discussed only with extreme caution, even ratios obtained from apparently fresh basalts. We believe that only two ${ }^{87} \mathrm{Sr} /{ }^{86} \mathrm{Sr}$ measurements can be safely used in the discussion: the least radiogenic one (DJ59), and the value obtained on the leached residue of DJ54B.

The $\mathrm{Sr}, \mathrm{Nd}$, and $\mathrm{Pb}$ isotopic compositions of the Hayyabley basalts are compared to those of other volcanics from the Horn of Africa in figures 4 to 6. In these plots, Hayyabley basalts lie significantly outside the fields defined by the submarine basalts erupted from the nascent oceanic ridges of the Red Sea, the Eastern part of the Tadjoura Gulf, and the Aden Gulf. These features indicate that these LREE-depleted lavas are unlike MORB (Figs. 5 and 6). For example, they display ${ }^{87} \mathrm{Sr} /{ }^{86} \mathrm{Sr}$ ratios more radiogenic than N-MORB, and significantly lower $\varepsilon_{\mathrm{Nd}}$ values (Ito et al., 1987). In contrast, the $\varepsilon$ Nd vs. ${ }^{87} \mathrm{Sr} /{ }^{86} \mathrm{Sr}$ plot (Fig. 4) shows that the Hayyabley basalts and LREE-depleted basalts from Manda Hararo are isotopically very similar. The Hayyabley basalts display almost uniform $\mathrm{Pb}$ isotopic compositions $\left({ }^{206} \mathrm{~Pb} /{ }^{204} \mathrm{~Pb}=18.47-18.55,{ }^{207} \mathrm{~Pb} /{ }^{204} \mathrm{~Pb}=15.52-15.57,{ }^{208} \mathrm{~Pb} /{ }^{204} \mathrm{~Pb}=38.62-38.77\right)$ well above the NHRL (Hart, 1984, 1988; see Table 4). In the Sr-Nd, Pb-Pb and Nd-Pb plots (Figs. 4 to 6), the Hayyabley basalts extend the range of the compositions displayed by the young $(<4 \mathrm{Ma})$ basalts from Djibouti. They might reflect the contribution of a distinct LREE component in their petrogenesis.

\section{Discussion}

Although Ethiopian Plateau basalts (Pik et al., 1999; Kieffer et al., 2004; Meshesha and Shinjo, 2007; Beccaluva et al., 2009), and Afar basalts (Treuil and Joron, 1975; Joron et al., 1980; Deniel et al., 1994) are dominantly enriched, previous studies (Barrat et al., 1993, 2003; Pik et al., 1999; Meshesha and Shinjo, 2007) have demonstrated that minor depleted components were also involved in their petrogenesis. The discovery of a new occurrence of LREE-depleted basalts in Djibouti, i.e. further east in the Afar rift setting, might provide new constrains on their origin. Two main points will be discussed below: (1) the origin of the Ba, Sr and Eu positive anomalies observed in the Hayyabley basalts, and (2) the occurrence of a specific LREE-depleted component in the sources of the Afar basalts. 
The origin of $\mathrm{Ba}, \mathrm{Sr}$ and $\mathrm{Eu}$ positive anomalies in LREE-depleted basalts has been previously investigated in the cases of some Icelandic basalts (e.g., Kokfelt et al., 2006 and references therein) and of the Manda Hararo basalts (Barrat et al., 2003). The compositions of LREE-depleted basalts such as those erupted by the Hayyabley volcano might be related to those of common MORB. The chief differences between them could be due to secondary processes, such as hot-desert weathering, crystal accumulation, or contamination by a crustal component. Alternatively, they could be derived from an unusual mantle source, located in the lithospheric or asthenospheric mantle or in the plume itself.

In a hot-desert environment, surface processes are able to generate positive $\mathrm{Ba}$ and $\mathrm{Sr}$ anomalies in a very short time. The studies of meteorites from Sahara have demonstrated that some of them, and not only the most weathered ones, exhibit marked $\mathrm{Ba}$ and Sr enrichments that are sensitive indicators of the development of secondary calcite, gypsum, or barytes (e.g., Barrat et al., 1998, 2003). Such processes would have generated a range of $\mathrm{Ba}$ and $\mathrm{Sr}$ abundances from low values typical of unweathered N-MORB (about $10 \mathrm{ppm} \mathrm{Ba}$ and 100 ppm Sr) to much higher concentrations. However, $\mathrm{Ba}$ and $\mathrm{Sr}$ abundances in the Hayyabley basalts are uniform, and strikingly similar to the concentrations measured in the distant Manda Hararo basalts. Furthermore, the development of secondary phases is unable to increase the $\mathrm{Eu} / \mathrm{Eu}^{*}$ ratio and to generate positive $\mathrm{Eu}$ anomalies, hence ruling out this first explanation.

Positive $\mathrm{Ba}, \mathrm{Sr}$ and $\mathrm{Eu}$ anomalies in basaltic rocks are usually explained by plagioclase accumulation or assimilation. However this process is unable to produce $\mathrm{Sr}$ anomalies as high as those displayed by the Hayyabley or Manda Hararo basalts without increasing drastically the $\mathrm{Al}_{2} \mathrm{O}_{3}$ contents of the resulting rocks. The fact that the $\mathrm{Al}_{2} \mathrm{O}_{3}$ abundances of the LREEdepleted basalts are not anomalously high (Table 2) is inconsistent with the hypothesis of plagioclase accumulation. Assimilation of plagioclase-rich gabbros from the oceanic lithosphere during ascent of plume-related magmas has been proposed in the cases of offshore Tadjoura Gulf basalts (Barrat et al., 1993) and Galapagos basalts (Saal et al., 2007). However, reproducing the compositions of Hayyabley basalts through this process, and especially their positive $\mathrm{Ba}, \mathrm{Sr}$ and $\mathrm{Eu}$ anomalies, would require rather high rates of assimilation. In addition, the Hayyabley and Manda Hararo basalts overlie thinned continental crust which is $25-26 \mathrm{~km}$ thick (Dugda and Nyblade, 2006), while the depleted plateau basalt sample E88 (Pik et al., 1999) is located on normal (ca. $40 \mathrm{~km}$ thick) African crust. Due to the presence of a 
crustal or even subcrustal depths of associated gabbroic cumulates. However, these gabbros should be LREE-enriched like the vast majority of Afar basalts. Therefore, their interaction with depleted (N-MORB type) melts is likely to lead to variably LREE-enriched magmas with isotopic compositions close to those of the flood basalts.

The Hayyabley basalts have radiogenic $\mathrm{Sr}$ isotopic compositions and low $\varepsilon \mathrm{Nd}$ values relative to Aden Gulf or Red Sea MORBs (Schilling et al., 1992; Volker et al., 1993; Hase et al., 2000). The assimilation of a continental component could explain this shift from usual NMORB values, but incompatible trace element ratios give no support to this interpretation. Contamination of MORB-like melts by continental crust would produce significant changes in incompatible trace element ratios. The Hayyabley basalts, like the Manda Hararo LREEdepleted basalts, lack the negative $\mathrm{Nb}$ or $\mathrm{Ta}$ anomalies observed in the multi-element plots of crust-contaminated basalts. Moreover, they show a limited range of $\mathrm{Ce} / \mathrm{Pb}$ ratios from 24 to 28, similar to values measured in oceanic basalts (e.g., Sun and McDonough, 1989). Therefore, there is no indication for assimilation of significant amounts of material derived from the continental crust in the LREE-depleted basalts. In the case of the Manda Hararo basalts, this conclusion is strengthened by their $\delta^{18} \mathrm{O}$ values close to $5.5 \%$, which are typical of mantle composition (Barrat et al., 2003).

Another possible explanation of the specific features of Hayyabley and Manda Hararo basalts is that they might result from the interaction between ascending depleted (N-MORB type) melts and the African subcontinental lithospheric mantle. Once again, such a mantle is expected to be LREE-enriched (Hart et al., 1989; Vidal et al., 1991; Deniel et al., 1994) and thus should transmit its trace element and isotopic fingerprint to LREE-poor ascending magmas. In addition, the remarkably similar chemical features of Hayyabley, Manda Hararo and E88 basalts suggest that they derive from almost identical sources and petrogenetic processes. Their distinct locations, emplacement ages (Oligocene for E88, ca. 1 Ma for Hayyabley and less than $0.2 \mathrm{Ma}$ for Manda Hararo) and underlying crustal/lithospheric thickness (normal for E88, thinned for the two other occurrences) are hardly consistent with a similar petrogenetic history.

Therefore, as previously pointed out for the Manda Hararo basalts (Barrat et al., 2003), the positive $\mathrm{Sr}, \mathrm{Ba}$ and $\mathrm{Eu}$ anomalies and the particular $\mathrm{Sr}-\mathrm{Nd}-\mathrm{Pb}$ isotopic features of the Hayyabley basalts, are more likely a genuine feature inherited from their deep mantle sources. The same conclusions have been reached for depleted basalts with similar positive anomalies from Iceland. Chauvel and Hémond (2000), Skovgaard et al. (2001), and Kokfelt et al. (2006) have suggested that the sources of Icelandic lavas contained an old recycled oceanic 
373 lithosphere component and that melting of the gabbroic portion of this lithosphere led to the

374 formation of basalts that exhibit large positive $\mathrm{Ba}, \mathrm{Sr}$ and $\mathrm{Eu}$ anomalies. At first glance, such 375 an explanation is attractive because if this recycled gabbroic component has been 376 hydrothermally altered, one may expect ${ }^{87} \mathrm{Sr} /{ }^{86} \mathrm{Sr}$ ratios much more radiogenic than those of typical MORB. Hence, the involvement of such component could account for the relatively high ${ }^{87} \mathrm{Sr} /{ }^{86} \mathrm{Sr}$ ratios of the Manda Hararo and Hayyabley depleted basalts. However, an old LREE-depleted recycled gabbroic component from the oceanic lithosphere would also be characterized by high $\varepsilon_{\mathrm{Nd}}$ values. On the contrary, the Manda Hararo and Hayyabley lavas display $\varepsilon_{\mathrm{Nd}}$ values unexpectedly low $\left(\varepsilon_{\mathrm{Nd}}=5-7\right)$ for depleted basalts. Thus, we conclude that, at best, this model only partially fits the observations.

\subsection{The depleted components in the sources of Djibouti and Ethiopian basalts}

Previous geochemical studies have demonstrated the participation of a depleted component during the genesis of the Horn of Africa basalts. In the case of basalts emitted by the young oceanic ridges from the Red Sea or the Aden Gulf, major involvement of MORBrelated sources has been proposed (e.g., Barrat et al., 1990, 1993; Schilling et al., 1992; Volker et al., 1993). These submarine basalts do not have the unradiogenic $\mathrm{Pb}$ isotopes of the Carslberg Ridge ca. $1600 \mathrm{~km}$ east of Hayyabley volcano (Hart, 1984) but do extend away from the Indian Ocean MORB toward a more HIMU composition. On land, huge volumes of enriched basalts were emplaced in Afar and Ethiopia. The trace element and isotopic features of the depleted reservoirs which have been involved during the genesis of the scarce LREEdepleted lavas are very difficult to constrain. Two distinct LREE-depleted components have been unambiguously detected.

First, a depleted MORB mantle component is clearly involved in the genesis of 398 Quaternary basalts from Northern Afar. The $\mathrm{Sr}-\mathrm{Nd}-\mathrm{Pb}$ isotopic relationships displayed by the Erta'Ale basalts (Figs. 4 to 6) point to the participation of two mantle end-members, namely a HIMU component and a depleted mantle (DM) component undistinguishable from the source of the Red Sea MORB (Barrat et al., 1998). Furthermore, a similar depleted component has been detected in the sources of the Oligocene lavas from the Northwestern Ethiopian volcanic province (Meshesha and Shinjo, 2007). The entrainment of depleted asthenospheric mantle during plume ascent (Furman et al., 2006) is a possible explanation for the contribution of this component to the sources of some of the basalts erupted in Afar and Ethiopia, as well as to those of Kerguelen basalts (Doucet et al., 2002). However, numerical models (Farnetani et al., 
2002; Farnetani and Samuel, 2005) suggest that incorporation of depleted upper mantle within ascending plumes is unlikely to occur.

In addition, the compositions of LREE-depleted basalts from Hayyabley and Manda Hararo point to a depleted end-member chemically (Fig. 3) and isotopically (Figs. 4 to 6) distinct from an asthenospheric MORB-like component. A single Oligocene LREE-depleted basalt displaying chemical features similar to those of the Quaternary depleted ones has been collected in Ethiopia (sample E88, Pik et al., 1999). Although its isotopic composition is slightly different from those of the Hayyabley basalts (Figs. 4 to 6), the occurrence of this sample indicates that a depleted component distinct from the MORB source was involved in this area at an early stage of plume emplacement. Therefore, we suggest that a depleted component, intrinsic to the plume at depth, has contributed to the sources of both young and old lavas related to the Afar plume. Similar conclusions have been reached for the Hawaiian (Frey et al., 2005) and Icelandic (Thirlwall, 1995; Kerr et al., 1995; Fitton et al., 1997; Chauvel and Hémond, 2000; Thirlwall et al., 2004; Skovgaard et al., 2001; Kokfelt et al., 2006) plumes. However, the nature of this component is currently difficult to constrain in the Afar case. Indeed, melting of the gabbroic part of an old recycled oceanic lithosphere (e.g., Kokfelt et al., 2006) would produce high $\varepsilon_{\mathrm{Nd}}$ magmas and therefore this process does not account for the low $\varepsilon_{\mathrm{Nd}}$ values of Hayyableh and Manda Hararo basalts. Alternatively, LREE depletion could be due to a previous melting event affecting the plume materials, as proposed by Thirlwall et al. (2004) for their ID2 (or RRD2) depleted component of the Icelandic plume. This hypothesis may account for the $\mathrm{Pb}$ isotopic differences between Hayyabley/Manda Hararo basalts and the other (enriched) Djibouti basalts (Figs. 4 to 6) but can hardly explain the higher Sr isotopic ratios of Hayyabley and Manda Hararo basalts.

Finally, another intriguing problem is the causal mechanism for the sporadic eruption of small volumes of such nearly pure "depleted" melts in spatially and temporally distinct locations, without any significant contamination by the dominant enriched materials. Indeed, such features are difficult to reconcile with models postulating a large concentrically-zoned Afar plume (e.g., Beccaluva et al., 2009). Numerical simulations of the evolution of thermal and thermo-chemical plumes (Farnetani et al., 2002; Farnetani and Samuel, 2005; Farnetani and Hofmann, 2009) suggest that small heterogeneous mantle domains present in the thermal boundary layer feeding the plume are converted, during the ascent of the latter, into long-lived elongated and narrow filaments within the plume conduit. Such filaments would melt sporadically, and then eventually communicate their specific geochemical fingerprint to small volumes of basaltic lavas (Farnetani and Hoffmann, 2009). 


\section{Conclusions}

The 1 Ma-old Hayyabley volcano (SE Djibouti) has emitted ca. $0.6-0.8 \mathrm{~km}^{3}$ of LREE-depleted basalts $\left(\mathrm{La}_{\mathrm{n}} / \mathrm{Sm}_{\mathrm{n}}=0.76-0.83\right)$ that display unusual chemical features (positive $\mathrm{Ba}, \mathrm{Sr}$ and $\mathrm{Eu}$ anomalies). These lavas are chemically distinct from the N-MORBs erupted from the nearby Red Sea and Gulf of Aden oceanic ridges, and instead closely resemble the LREE-depleted basalts from the Manda Hararo rift in Central Afar (Barrat et al., 2003). Another similar occurrence, Oligocene in age, has been reported from the trap series in the Ethiopian Plateau by Pik et al. (1999). Our new results confirm the presence within the Afar region of basalts derived from an uncommon depleted component, isotopically distinct from the source of the Red Sea MORBs and from the similarly depleted mantle (DM in Figs. 4 to 6) which contributes to the genesis of Erta'Ale volcanics (Barrat et al., 1998). This component

454 is not unusual from an isotopic $(\mathrm{Sr}, \mathrm{Nd}, \mathrm{Pb}, \mathrm{O})$ point of view, and is mainly recognizable from the specific trace element signature of the corresponding basalts (positive $\mathrm{Ba}, \mathrm{Sr}, \mathrm{Eu}$ anomalies combined with LREE depletion).

The origin of the Hayyabley-Manda Hararo basalts fingerprint could be ascribed to the interactions between (i) depleted (N-MORB type) basalts derived from an asthenospheric mantle component similar to the Erta 'Ale depleted end-member and (ii) enriched lithospheric materials which would be responsible for the positive $\mathrm{Ba}, \mathrm{Sr}$ and $\mathrm{Eu}$ anomalies. These materials could be either the African continental crust, flood basalt-related gabbroic cumulates stored within or below it, or finally the subcontinental lithospheric mantle. Hovever, all these materials are mostly LREE-enriched, and the contamination hypothesis can hardly explain the clear LREE, $\mathrm{Rb}$ and $\mathrm{Th}$ depletion and concomitant $\mathrm{Ba}, \mathrm{Sr}$ and $\mathrm{Eu}$ enrichment of Hayyabley basalts (Figs. 2 and 3) as well as their Pb isotopic signature (Figs. 5 and 6). Moreover, contamination in plume-related volcanic series is often described as a variable, occasional or random process. Thus, it can hardly account for the very specific trace element and isotopic signature of the Afar depleted basalts, which were erupted in three separate locations, with distinct emplacement ages and underlying crustal/lithospheric thickness.

Therefore, our preferred conclusion is that these depleted basalts derive from a intrinsic (although volumetrically minor) depleted component from the Afar plume, possibly present as elongated and narrow filaments within the plume conduit. Sporadic melting of such filaments 
might account for the restricted spatial and temporal distribution of the Afar depleted basalts. The precise origin of this deep mantle component is currently difficult to constrain, given the small number of depleted basalt samples and the limited amount of corresponding geochemical data. The most likely hypothesis is the contribution of recycled gabbros from ancient oceanic crust.

\section{Acknowledgements}

This study has been funded by the French Embassy in Djibouti, and the grant of the first author (M.A.D.) provided by the MAWARI international program managed by the CIFEG, Orléans, France. Analytical expenses were funded by the MAWARI program and UMR 6538, Plouzané. We especially thank Dr. Mohamed Jalludin, Director of the CERD, for his interest, scientific discussions and logistic support, Ali Abdillahi for his efficiency in organizing fieldwork, and Marcel Bohn for his help with microprobe analysis. Careful reviews by Tania Furman and Godfrey Fitton led us to improve significantly the organization and contents of this manuscript.

\section{References}

Baker, J.A., Thirlwall, M.F., Menzies, M.A., 1996. Sr-Nd-Pb isotopic and trace element evidence for crustal contamination of plume-derived flood basalts: Oligocene flood volcanism in Western Yemen. Geochimica et Cosmochimica Acta 60, 2559-2581.

Barberi, F., Ferrara, G., Santacroce, R., Varet, J., 1975. Structural evolution of the Afar triple junction. In: Pilger, A., Rösler, A., (Eds.) Afar Depression of Ethiopia. Schweizerbart, Stuttgart, 38-54.

Barberi, F., Varet, J., 1977. Volcanism in Afar, small scale plate tectonics implications. Geological Society of America Bulletin 88, 1251-1266.

Barrat, J.A., Keller, F., Amossé, J., Taylor, R.N., Nesbitt, R.W., Hirata, T., 1996. Determination of rare earth elements in sixteen silicate reference samples by ICP-MS after Tm addition and ion exchange separation. Geostandards Newsletter 20, 133-139.

Barrat, J.A., Fourcade, S., Jahn, B.M., Cheminée, J.L., Capdevila, R., 1998. Isotope (Sr, Nd, $\mathrm{Pb}, \mathrm{O})$ and trace-element geochemistry of volcanics from the Erta'Ale range (Ethiopia). Journal of Volcanology and Geothermal Research 80, 85-100. 
Barrat, J.A, Jahn, B.M., Joron, J.L., Auvray, B., Hamdi, H., 1990. Mantle heterogeneity in northeastern Africa: evidence from $\mathrm{Nd}$ isotopic compositions and hygromagmaphile element geochemistry of basaltic rocks from the Gulf of Tadjoura and Southern Red Sea regions. Earth and Planetary Science Letters 101, 233-247.

Barrat, J.A., Jahn, B.M., Fourcade, S., Joron, J.L., 1993. Magma genesis in an ongoing rifting zone: the Tadjoura Gulf. Geochimica et Cosmochimica Acta 57, 2291-2302.

Barrat, J.A., Blichert-Toft, J., Gillet, P., Keller, F., 2000. The differentiation of eucrites: the role of in situ crystallization. Meteoritics \& Planetary Science 35, 1087-1100.

Barrat, J.A., Joron, J.L., Taylor, R.N., Fourcade, S., Nesbitt, R.W., Jahn, B.M., 2003. Geochemistry of basalts from Manda Hararo, Ethiopia: LREE-depleted basalts in Central Afar. Lithos 69, p. 1-13.

Barrat, J.A., Yamaguchi, A., Greenwood, A., Bohn, M., Cotten, J., Benoit, M., Franchi, I.A., 2007. The Stannern trend eucrites: contamination of main group eucritic magmas by crustal partial melts. Geochimica et Cosmochimica Acta 71, 4108-4124.

Beccaluva, L., Bianchini, G., Natali, C., Siena, F., 2009. Continental flood basalts and mantle plumes: a case study of the Northern Ethiopian Plateau. Journal of Petrology 50, 1377-1403.

Blichert-Toft, J., White, W.M., 2001. Hf isotope geochemistry of the Galapagos Islands. Geochemistry, Geophysics, Geosystems 2, doi:10.129/2000GC000138.

Charbit, S., Guillou, H., Turpin, L., 1998. Cross calibration of K-Ar standard minerals using trace element and $\mathrm{Pb}$ isotopic evidence from Iceland. Geochemistry, Geophysics, Geosystems 1, paper number 1999GC000002. 
Chen, C.-Y., Frey, F.A., 1985. Trace element and isotope geochemistry of lavas from Halaakala Volcano, East Maui: implications for the origin of Hawaiian basalts. Journal of Geophysical Research 90, 8743-8768. M., Brousse, R., 1995. Origin of anomalous rare-earth element and yttrium enrichments in subaerially exposed basalts: Evidence from French Polynesia.

Courtillot, V., Galdeano, A., Le Mouel, J.-L., 1980. Propagation of an accreting plate Chemical Geology 119, 115-138. boundary: a discussion of new magnetic data in the Gulf of Tadjoura and Southern Afar.

Courtillot, V., Achache, J., Landre, F., Bonhommet, N., Montigny, R., Féraud, G., 1984. Episodic spreading and rift propagation: new paleomagnetic and geochronologic data from the Afar nascent passive margin. Journal of Geophysical Research 89, 3315-3333.

Daoud, M.A., 2008. Dynamique du rifting continental de 30 Ma à l'Actuel dans la partie sud-est du Triangle Afar. Tectonique et magmatisme du rift de Tadjoura et des

Defant, M.J., Maury, R.C., Ripley, E.M., Feigenson, M.D., Jacques, D., 1991. An example domaines Danakil et d'Ali Sabieh, République de Djibouti. Thèse, Université de Bretagne Occidentale, Brest, 190 p. of island-arc petrogenesis: geochemistry and petrology of the southern Luzon arc, Philippines. Journal of Petrology 32, 455-500. Atlantic Ridge, $10^{\circ}-24^{\circ} \mathrm{N}$ : trace element-isotope complementary. Earth and Planetary Science Letters 120, 443-462. 
Doucet, S., Weis, D., Scoates, J.S., Nicolaysen, K., Frey, F.A., Giret, A., 2002. The depleted mantle component in Kerguelen Archipelago basalts: petrogenesis of tholeiitictransitional basalts from the Loranchet Peninsula. Journal of Petrology 43, 1341-1366.

Dugda, M.T., Nyblade, A.A., 2006. New constraints on crustal structure in eastern Afar 582 from the analysis of receiver functions and surface wave dispersion in Djibouti. In: Yirgu, G., Ebinger, C.J., Maguire, P.K.H., (Eds.), The Afar volcanic province within the

Evensen, N.M., Hamilton, P.J., O'Nions, R.K., 1978. Rare Earth abundances in chondritic 589

Farnetani, C.G., Legras, B., Tackley, P.J., 2002. Mixing and deformation in mantle plumes. 592

Farnetani, C.G., Samuel, H., 2005. Beyond the thermal plume paradigm. Geophysical 594 595 Earth and Planetary Science Letters, 196, 1-15.

602 Research Letters, 32, L07311, doi:10.129/2005GL022360.

Farnetani, C.G., Hofmann, A.W., 2009. Dynamics and internal structure of a lower mantle plume conduit. Earth and Planetary Science Letters, 282, 314-322.

Fitton, J.G., Saunders, A.D., Norry, M.J., Hardason, B.S., Taylor, R.N., 1997. Thermal and chemical structure of the Iceland plume. Earth and Planetary Science Letters, 153, 197208.

606 
Fournier, M., Gasse, F., Lépine, J.-C., Richard O., Ruegg J.C., 1982. Carte géologique de la République de Djibouti à 1:100 000. Djibouti. ISERST. Ministère français de Coopération. Ed. ORSTOM, Paris.

Frey, F.A., Huang, S., Blichert-Toft, J., Regelous, M., Boyet, M., 2005. Origin of depleted components in basalt related to the Hawaiian hot spot: Evidence from isotopic and incompatible element ratios. Geochemistry, Geophysics, Geosystems 6, Q02L07, doi:10.129/2004GC000757.

Fuhrmann, U., Lippolt, H., Hess, J.C., 1987. HD-B1 Biotite reference material for K-Ar chronometry. Chemical Geology 66, 41-51.

Furman, T., Bryce, J., Rooney, T., Hana, B., Yirgu, G., Ayalew, D., 2006. Heads and tails: 30 million years of the Afar plume. In: Yirgu, G., Ebinger, C.J., Maguire, P.K.H., (Eds.), The Afar volcanic province within the East African Rift System. Geological Society of London, Special Publication 259, 95-119.

Gasse, F., Fournier, M., Richard, O., Ruegg, J.C., 1983. Carte géologique de la République de Djibouti à 1:100 000. Djibouti. Notice explicative. ISERST, Ministère français de la Coopération, Ed. ORSTOM, Paris, 70 pp.

Guillou, H., Singer, B., Laj, C., Kissel, C., Scaillet, S., Jicha, B.R., 2004. On the age of the Laschamp geomagnetic event. Earth and Planetary Science Letters, 227, 331-343.

Hart, S.R., 1984. A large-scale isotope anomaly in the Southern Hemisphere mantle. Nature 309, 753-757.

Hart, S.R., 1988. Heterogeneous mantle domains: signatures, genesis and mixing chronologies. Earth and Planetary Science Letters 90, 273-296.

Hart, S.R., Hauri, E.H., Oschmann, L.A., Whitehead, J.A., 1992. Mantle plumes and entrainment: isotopic evidence. Science 256, 517-520. 
Hart, W.K., Woldegabriel, G., Walter, R.C., Mertzman, S.A., 1989. Basaltic volcanism in Ethiopia: constraints on continental rifting and mantle interactions. Journal of Geophysical Research 94, 7731-7748.

Hase, K.M., Mühe, R., Stoffers, P., 2000. Magmatism during extension of the lithosphere: geochemical constraints from lavas of the Shaban Deep, northern Red Sea. Chemical Geology 166, 225-239.

Hémond, C., Arndt, N.T., Lichtenstein, U., Hofmann, A., 1993. The heterogeneous Iceland plume: Nd-Sr-O isotopes and trace element constraints. Journal of Geophysical Research 98, 15803-15850.

Hoernle, K., Werner, R., Phipps-Morgan, J., Garbe-Schönberg, D., Bryce, J., Mrazek, J., 2000. Existence of complex spatial zonation in the Galapagos plume for at least $14 \mathrm{~m}$. y. Geology 28, 435-438.

Ishizuka, O., Taylor, R.N., Milton, J.A., Nesbitt, R.W., 2003. Fluid-mantle interaction in an intraoceanic arc: constraints from high-precision $\mathrm{Pb}$ isotopes. Earth and Planetary Science Letters 211, 221-236.

Ito, E., White, W.M., Göpel, C., 1987. The O, Sr, Nd, and Pb isotope geochemistry of MORB. Chemical Geology 62, 157-176.

Joron, J.L., Treuil, M., Jaffrezic, H., Villemant, B., Richard, O., 1980. Géochimie des éléments en traces du volcanisme de l'Afar et de la mégastructure Mer Rouge-AfarGolfe d'Aden. Implications pétrogénétiques et géodynamiques. Bulletin de la Société géologique de France (7) 22, 945-957.

Johnson, C.M., Beard, B.L., 1999. Correction of instrumentally produced mass fractionation during isotopic analysis of Fe by thermal ionization mass spectrometry, International Journal of Mass Spectrometry 193, 87-99.

Kerr, A.C., Saunders, A.D., Tarney, J., Berry, N.H., Hards, V.L., 1995. Depleted mantleplume geochemical signatures: No paradox for plume theories. Geology 23, 843-846. 
Kokfelt, T.F., Hoernle, K., Hauf, F., Fiebig, J., Werner, R., Garbe-Schomberg, D., 2006. Combined trace element and $\mathrm{Pb}-\mathrm{Nd}-\mathrm{Sr}-\mathrm{O}$ isotope evidence for recycled oceanic crust(upper and lower) in the Iceland mantle plume. Journal of Petrology 47, 17051749.

679

Laughlin, A.W., Poths, S., Healey, H., Reneau, S., Woldegabriel, G., 1994. Dating Quaternary basalts using the $3 \mathrm{He}$ and $14 \mathrm{C}$ methods with implications for excess Ar.

Lin, S.-S., Keken, P.E. van, 2006. Dynamics of thermochemical plumes: 2. Complexity of 685 plume structures and its implications for mapping mantle plumes. Geochemistry, Geophysics, Geosystems 7, Q033003, doi:10.129/2005GC001072.

Manighetti, I., Tapponnier, P., Courtillot, V., Gruszow, S., Gillot., P.Y., 1997. Propagation 691

Meshesha, D., Shinjo, R., 2007. Crustal contamination and diversity of magma sources in 693 the Northwestern Ethiopian volcanic province. Journal of Mineralogical and Petrological Sciences, 102, 272-290.

Needham, H.D., Choukroune, P., Cheminée, J.-L., Le Pichon, X., Francheteau, J., 699

Odin, G.S., and 35 collaborators, 1982. Interlaboratory standards for dating purposes. In: 702 northwestern Ethiopian Plateau flood basalts: Classification and spatial distribution of magma types. Journal of Volcanology and Geothermal Research 81, 91-111. 
Pik, R., Deniel, C., Coulon, C., Yirgu, G., Marty, B., 1999. Isotopic and trace element signatures of Ethiopian flood basalts: evidence for plume-lithosphere interactions. Geochimica et Cosmochimica Acta 63, 2263-2279.

Rogers, N.W., 2006. Basaltic magmatism and the geodynamics of the East African Rift province within the East African Rift System. Geological Society of London, Special Publication 259, 77-93.

Scaillet, S., Guillou, H., 2004. A critical evaluation of young (near-zero) K-Ar ages. Earth and Planetary Science Letters 220, 265-275.

Schilling, J.G., 1973. Afar mantle plume: rare earth evidence. Nature 242, 2-5.

Schilling, J.G., Kingsley, R.H., Hanan, B.B., McCully, B.L., 1992. Nd-Sr-Pb variations along the Gulf of Aden: evidence for Afar Mantle plume-continental lithosphere interaction. Journal of Geophysical Research 97, 10927-10966.

Steiger, R.H., Jäger, E., 1977. Subcommission on geochronology: convention on the use of decay constants in geo- and cosmochronology. Earth and Planetary Science Letters 36,

Skovgaard, A.C., Storey, M., Baker, J., Blusztajn, J., Hart, S.R., 2001. Osmium-oxygen isotopic evidence for a recycled and strongly depleted component in the Iceland mantle plume. Earth and Planetary Science Letters 194, 259-275. 359-362. 
Stieltjes, L., Joron, J.L., Treuil, M., Varet, J., 1976. Le rift d'Asal, segment de dorsale émergée: discussion pétrologique et géochimique. Bulletin de la Société géologique de France (7) 18, 851-862.

Sun, S.S., McDonough, W.F., 1989. Chemical and isotopic systematics of oceanic basalts: Implications for mantle composition and processes. In: Saunders, A.D., Norry, M.J., (Eds.), Magmatism in the ocean basins. Geological Society of London Special Publication 42, 313-345.

Taylor, R.N., Thirlwall, M.F., Murton, B.J., Hilton, D.R., Gee, M.A.M., 1997. Isotopic constraints on the influence of the Icelandic plume. Earth and Planetary Science Letters $148,1-8$.

Thirlwall, M.F., 1995. Generation of the Pb isotopic characteristics of the Iceland plume. Journal of the Geological Society of London, 152, 991-996.

Thirlwall, M.F., Gee, M.A.M., Taylor, R.N., Murton, B.J., 2004. Mantle components in Iceland and adjacent ridges investigated using double-spike $\mathrm{Pb}$ isotope ratios. Geochimica et Cosmochimica Acta 68, 361-386.

Treuil, M., Joron, J.L., 1975. Utilisation des éléments hygromagmatophiles pour la simplification de la modélisation quantitative des processus magmatiques. Exemples de l'Afar et de la dorsale médioatlantique. Rendiconti della Società Italiana di Mineralogia e Petrologia 31, 125-174.

Vidal, P., Deniel, C., Vellutini, P.J., Piguet, P., Coulon, C., Vincent, J., Audin, J., 1991. Changes of mantle sources in the course of a rift evolution: the Afar case. Geophysical Research Letters 18, 1913-1916.

Volker, F., Altherr, R., Jochum, K.P., McCulloch, M.T., 1997. Quaternary volcanic activity of the southern Red Sea: new data and assessment of models on magma sources and Afar plume-lithosphere interaction. Tectonophysics 278, 15-29. 
Volker, F., McCulloch, M.T., Altherr, R.,1993. Submarine basalts from the Red Sea: new $\mathrm{Pb}, \mathrm{Sr}$, and Nd isotopic data. Geophysical Research Letters 20, 927-930.

White, W.M., McBirney, A.R., Duncan, R.A., 1993. Petrology and geochemistry of the Galapagos islands: portrait of a pathological mantle plume. Journal of Geophysical Research 98, 19533-19563.

Yang, H.-J., Frey, F.A., Clague, D.A., 2003. Constraints on the source components of lavas 783 forming the Hawaiian North Arch and Honolulu volcanoes. Journal of Petrology 44, 785 603-627.

Zindler, A., Hart, S.R., Frey, F.A., Jakobsson, S.P., 1979. Nd and $\mathrm{Sr}$ isotope ratios and rare 791 earth abundances in Reykjanes Peninsula basalts: evidence for mantle heterogeneity

\section{Figure captions}

799

800

801

802

Fig. 1. Geological setting of the Djibouti Plain. (a) Location of the study area in the Tadjoura 803

Fig. 2. Chondrite-normalized REE patterns of Hayyableh basalts compared to the field of older Tadjoura Gulf basalts located onland in Djibouti (Barrat et al., 1993; Daoud, 2008). The reference chondrite is from Evensen et al. (1978). The pattern of a southern Red Sea NMORB (sample V84, Barrat etal., 1990) is shown for comparison. 
Fig. 3. Primitive mantle-normalized element patterns for Hayyabley basalts, LREE-depleted Manda Hararo basalts (Barrat et al., 2003), two submarine MORB from the East of the Gulf of Tadjoura (Barrat et al., 1990, 1993), the southern Red Sea N-MORB sample V84 (Barrat et al., 1990), and the LREE-depleted sample E88 from the Oligocene Ethiopian Plateau (Pik et al., 1999). The primitive mantle values are from Sun and McDonough (1989).

Fig. 4. Plot of $\varepsilon_{\mathrm{Nd}}$ vs. ${ }^{87} \mathrm{Sr} /{ }^{86} \mathrm{Sr}$ for young onland basalts from Djibouti (Deniel et al., 1994, and this study). Only the two reliable Sr isotopic ratios of Hayyabley basalts have been plotted. Basalts older than $4 \mathrm{Ma}$ have been omitted because of their possible contamination by continental crust. The fields of (1) basalts from the South Red Sea occurrences, which include oceanic ridge segments, Ramad seamount and Zubair and Hanish islands (Barrat et al., 1990, 1993; Volker et al., 1993, 1997), (2) submarine basalts from the East of the Gulf of Tadjoura and the Aden Gulf (Barrat et al., 1990, 1993; Schilling et al., 1992), (3) Erta 'Ale volcanics (Barrat et al., 1998), (4) LREE-depleted basalts from Manda Hararo (MH, Barrat et al., 2003), and (5) some Ethiopian samples (E88: depleted Oligocene basalt; HT2: average composition of high-Ti basalts, Pik et al., 1999) are shown for comparison. DM refers to the regional depleted mantle composition deduced from the study of South Red Sea and Gulf of Aden basalts.

Fig. 5. Plot of ${ }^{207} \mathrm{~Pb} /{ }^{204} \mathrm{~Pb}$ and ${ }^{208} \mathrm{~Pb} /{ }^{204} \mathrm{~Pb}$ vs. ${ }^{206} \mathrm{~Pb} /{ }^{204} \mathrm{~Pb}$ for young (less than $4 \mathrm{Ma}$ ) onland enriched basalts from Djibouti (Deniel et al., 1994) and Hayyabley depleted basalts (this study). Other fields as in Fig. 4. E'A: field of Erta 'Ale volcanics (Barrat et al., 1998). Most ${ }^{207} \mathrm{~Pb} /{ }^{204} \mathrm{~Pb}$ data taken from the regional literature (e.g. on E88 and Erta 'Ale) are less precise than those measured on Hayyabley basalts, and should therefore be considered with caution.

Fig. 6. Plot of ${ }^{206} \mathrm{~Pb} /{ }^{204} \mathrm{~Pb}$ vs. $\varepsilon_{\mathrm{Nd}}$ for young (less than $4 \mathrm{Ma}$ ) onland enriched basalts from Djibouti (Deniel et al., 1994) and Hayyabley depleted basalts (this study). Other fields as in Fig. 5.

Table captions

Table 1. Unspiked ${ }^{40} \mathrm{~K}-{ }^{40} \mathrm{Ar}$ datings of Hayyabley basalts. See text for the analytical procedures. 
843 Table 2. Major and trace element analyses of Hayyabley basalts (major oxides in wt\%, trace

844 elements in ppm). ICP-AES and ICP-MS analytical methods described in the text.

845

846 Table 3. Compositions of LREE-depleted basalts from Hayyabley (average of the samples 847 analysed by ICP-MS), Manda Hararo (average data from Barrat et al., 2003), Ethiopian 848 Plateau (sample E88, Pik et al., 1999), and of a N-MORB from Tadjoura Gulf (sample A3D3, 849 Joron et al., 1980; Barrat et al., 1993). Major oxides in wt\%, trace elements in ppm. n denotes 850 ratios normalized to the primitive mantle composition from Sun and McDonough (1989).

851

852 Table 4. Sr, $\mathrm{Nd}$ and $\mathrm{Pb}$ isotopic compositions of Hayyabley basalts (B: bulk rock; R: residue 853 after leaching). See text for the analytical procedures. $\Delta 7 / 4$ and $\Delta 8 / 4$ denote the deviation (in $854{ }^{0} \%$ ) of ${ }^{207} \mathrm{~Pb} /{ }^{204} \mathrm{~Pb}$ and ${ }^{208} \mathrm{~Pb} /{ }^{204} \mathrm{~Pb}$ ratios with respect to the Northern Hemisphere Reference 855 Line (NHRL: Hart, 1984, 1988). 


\section{1}

\title{
A LREE-depleted component in the Afar plume: further evidence from Quaternary Djibouti basalts
}

\author{
Mohamed A. Daoud ${ }^{\text {a,b }}$, René C. Maury ${ }^{a^{*}}$, Jean-Alix Barrat ${ }^{a}$, Rex N. \\ Taylor $^{c}$, Bernard Le Gall ${ }^{a}$, Hervé Guillou ${ }^{\text {d }}$, Joseph Cotten ${ }^{\text {a }}$, Joël Rolet ${ }^{\text {a }}$ \\ a Université Européenne de Bretagne, Université de Brest; CNRS; UMR 6538 Domaines Océaniques; \\ Institut Universitaire Européen de la Mer, Place N. Copernic, 29280 Plouzané, France. \\ ${ }^{\mathrm{b}}$ Centre d'Etudes et de Recherches Scientifiques de Djibouti, B.P. 486, Djibouti. \\ ${ }^{\mathrm{c}}$ School of Ocean and Earth Science, NOC, University of Southampton, Southampton SO14 3ZH, UK. \\ ${ }^{d}$ UMR 1572 LSCE/CEA-CNRS, Domaine du CNRS, 12 avenue de la Terrasse, 91118 Gif-sur-Yvette, \\ France.
}

* Corresponding author. Tel.: (33)298498708; fax: (33)298498760

E-mail address: maury@univ-brest.fr

\begin{abstract}
Major, trace element and isotopic ( $\mathrm{Sr}, \mathrm{Nd}, \mathrm{Pb}$ ) data and unspiked $\mathrm{K}-\mathrm{Ar}$ ages are presented for Quaternary (0.90-0.95 Ma old) basalts from the Hayyabley volcano, Djibouti. These basalts are LREE-depleted $\left(\mathrm{La}_{\mathrm{n}} / \mathrm{Sm}_{\mathrm{n}}=\right.$ 0.76-0.83), with ${ }^{87} \mathrm{Sr} /{ }^{86} \mathrm{Sr}$ ratios ranging from 0.70369 to 0.70376 , and rather homogeneous ${ }^{143} \mathrm{Nd} /{ }^{144} \mathrm{Nd}\left(\varepsilon_{\mathrm{Nd}}=\right.$ $+5.9-+7.3)$ and $\mathrm{Pb}$ isotopic compositions $\left({ }^{206} \mathrm{~Pb} /{ }^{204} \mathrm{~Pb}=18.47-18.55,{ }^{207} \mathrm{~Pb} /{ }^{204} \mathrm{~Pb}=15.52-15.57,{ }^{208} \mathrm{~Pb} /{ }^{204} \mathrm{~Pb}=\right.$ 38.62-38.77). They are very different from the underlying enriched Tadjoura Gulf basalts, and from the NMORB erupted from the nascent oceanic ridges of the Red Sea and Gulf of Aden. Their compositions closely resemble those of (1) depleted Quaternary Manda Hararo basalts from the Afar depression in Ethiopia and (2) one Oligocene basalt from the Ethiopian Plateau trap series. Their trace element and $\mathrm{Sr}, \mathrm{Nd}, \mathrm{Pb}$ isotope systematics suggest the involvement of a discrete but minor LREE-depleted component, which is probably an intrinsic part of the Afar plume.
\end{abstract}

\section{Introduction.}

The study of basalts from intra-oceanic islands and plateaus as well as from traps and rifts has shown the considerable chemical heterogeneity of plume materials (Hart, 1988). This 
heterogeneity might indicate very complex plume structures and dynamics (Lin and van Keken, 2006). However, it may not only result from the initial chemical heterogeneity of mantle plumes at depth but also from the entrainment of surrounding mantle materials (Hart et al., 1992; Furman et al., 2006). In addition, a lithospheric component is clearly recognized in some intracontinental basalts, e.g. in the Afar province, but its origin is still debated (Rogers, 2006). Some authors have suggested that melting of the Afar lithospheric mantle explains a significant proportion of the erupted lavas (Hart et al., 1989; Vidal et al., 1991; Deniel et al., 1994) whilst others point out that continental crust contamination can also contribute to the isotopic signature of these basalts (Barrat et al., 1993; Baker et al., 1996; Pik et al., 1999).

The vast majority of plume-related basalts, including the Afar ones (Furman et al., 2006; Beccaluva et al., 2009) are dominated by a component that is chemically and isotopically enriched. However, the occurrence of subordinate components characterized by a light rare earth element (LREE) depletion has been suggested from the study of basalts from major mantle plumes in: (1) Iceland (Zindler et al., 1979; Hémond et al., 1993; Taylor et al., 1997; Chauvel and Hémond, 2000; Skovgaard et al., 2001; Fitton et al., 2003; Thirlwall et al., 2004; Kokfelt et al., 2006); (2) Hawaii (Chen and Frey, 1985; Yang et al., 2003; Frey et al., 2005); (3) the Galapagos (White et al., 1993; Hoernle et al., 2000; Blichert-Toft and White, 2001; Saal et al., 2007); and (4) the Kerguelen Archipelago (Doucet et al., 2002). However, the characterization of this reservoir is difficult because its signature may be overprinted by either the dominant enriched plume component or the lithospheric reservoirs. Therefore, the presence of an intrinsic depleted component in plumes is still an open question.

LREE-depleted basalts associated to the Afar mantle plume have long been recognized in the Quaternary Manda Hararo volcanic chain, Ethiopia (Treuil and Joron, 1975; Joron et al., 1980; Barrat et al., 2003). A single LREE-depleted Oligocene Ethiopian Plateau basalt has also been so far analysed (sample E88: Pik et al., 1998, 1999). The purpose of this paper is: (1) to describe another newly discovered occurrence of such basalts in the SE part of the Afar triangle, i.e. the rather large Hayyabley Quaternary volcano in Djibouti (Fig. 1), and (2) to discuss its bearing on the composition and heterogeneity of the Afar mantle plume.

\section{Analytical techniques}

Ar isotopic compositions and $\mathrm{K}$ contents (Table 1) were measured at Gif-sur-Yvette and IUEM (Institut Universitaire Européen de la Mer), respectively. The samples were crushed, sieved to $0.25-0.125 \mathrm{~mm}$ size fraction and ultrasonically washed in acetic acid. Potassium and 
argon were measured on the microcrystalline groundmass, after removal of phenocrysts using heavy liquids of appropriate densities and magnetic separations. This process improves the $\mathrm{K}$ yield as well as the percentage of radiogenic argon, and removes at least some potential sources of systematic error due to the presence of excess ${ }^{40} \mathrm{Ar}$ in olivine and feldspar phenocrysts (Laughlin et al., 1994). Ar analyses were performed using the procedures detailed in Yurtmen et al. (2002) and Guillou et al. (2004). The unspiked technique differs from the conventional isotope dilution method in that argon extracted from the sample is measured in sequence with purified aliquots of atmospheric argon at the same working gas pressure in the mass-spectrometer. This suppresses mass discrimination effects between the atmospheric reference and the unknown, and allows quantities of radiogenic ${ }^{40} \mathrm{Ar}^{*}$ as small as $0.14 \%$ to be detected on a single-run basis (Scaillet et al., 2004). Argon was extracted by radio frequency heating of $2.0-3.0 \mathrm{~g}$ of sample, then transferred to an ultra-high-vacuum glass line and purified with titanium sponge and $\mathrm{Zr}$-Ar getters. Isotopic analyses were performed on total ${ }^{40} \mathrm{Ar}$ contents ranging between 2.4 and $3.2 \times 10^{-11}$ moles using a $180^{\circ}, 6 \mathrm{~cm}$ radius mass spectrometer with an accelerating potential of $620 \mathrm{~V}$. The manometric calibration (Charbit et al.,1998) was based on periodic, replicate determinations of international dating standards including LP-6 (Odin et al., 1982) and HD-B1 (Fuhrmann et al., 1987). The total ${ }^{40} \mathrm{Ar}$ content of the sample can be determined with a precision of $\pm 0.2 \%(2 \sigma)$ according to this procedure. Ages were calculated using the constants recommended by Steiger and Jäger (1977).

Major element compositions of minerals and glasses were determined using a Cameca SX50 five spectrometer automated electron microprobe (Microsonde Ouest, Plouzané, France). Analytical conditions were $15 \mathrm{kV}, 10-12 \mathrm{nA}$ and a counting time of 6 sec. (see Defant et al., 1991, for further analytical details). Major and trace element data on bulk rocks (Table 2) were first obtained by Inductively Coupled Plasma-Atomic Emission Spectrometry (ICP-AES) at IUEM, Plouzané. The samples were finely powdered in an agate grinder. International standards were used for calibration tests (ACE, BEN, JB-2, PM-S and WS-E). $\mathrm{Rb}$ was measured by flame emission spectroscopy. Relative standard deviations are $\pm 1 \%$ for $\mathrm{SiO}_{2}$, and $\pm 2 \%$ for other major elements except $\mathrm{P}_{2} \mathrm{O}_{5}$ and $\mathrm{MnO}$ (absolute precision $\pm 0.01 \%$ ), and ca. 5\% for trace elements. The analytical techniques are described in Cotten et al. (1995). Concentrations of additional trace elements were measured by Inductively Coupled Plasma Mass Spectrometry (ICP-MS) at IUEM, using a Thermo Element 2 spectrometer following procedures adapted from Barrat et al. (1996, 2000). Based on standard measurements and sample duplicates, trace element concentration reproducibility is generally better than $5 \%$ (Barrat et al., 2007), and are in good agreement with the ICP-AES results (Table 2). 
Isotopic compositions of $\mathrm{Sr}$ and $\mathrm{Nd}$ (Table 4) were determined at IUEM. Conventional ion exchange techniques were used for separation of $\mathrm{Sr}$, and isotope ratio measurements were carried out by thermal ionization mass spectrometry using a Thermo Triton equipped with 7 collectors. Isotopic ratios were normalized for instrumental mass fractionation relative to ${ }^{86} \mathrm{Sr} /{ }^{88} \mathrm{Sr}=0.1194 .{ }^{87} \mathrm{Sr} /{ }^{86} \mathrm{Sr}$ of the NBS $987 \mathrm{Sr}$ standard yielded $0.710213 \pm 22(2 \sigma, \mathrm{n}=14)$ and the sample $\mathrm{Sr}$ isotopic compositions are reported relative to ${ }^{87} \mathrm{Sr} /{ }^{86} \mathrm{Sr}=0.71024$. The $\mathrm{Nd}$ purification was done according to the procedure described in Dosso et al. (1993). TRU Spec chromatographic resins from Eichrom were used to separate the REE fraction from the sample matrix. Then, the separation and elution of $\mathrm{Nd}$ and other REE were realized on Ln.Spec resin. During the course of the study, analyses of the La Jolla standard were performed and gave an average of ${ }^{143} \mathrm{Nd} /{ }^{144} \mathrm{Nd}=0.511845 \pm 6(\mathrm{n}=15)$. All $\mathrm{Nd}$ data were fractionation-corrected to ${ }^{146} \mathrm{Nd} /{ }^{144} \mathrm{Nd}=0.7219$ and further normalized to a value of ${ }^{143} \mathrm{Nd} /{ }^{144} \mathrm{Nd}=0.511860$ for the $\mathrm{La}$ Jolla standard.

Isotopic compositions of $\mathrm{Pb}$ were determined at the National Oceanography Centre, Southampton, using the SBL 74 double spike. Powdered samples were leached with $6 \mathrm{M} \mathrm{HCl}$ at $140^{\circ} \mathrm{C}$ for 1 hour and then rinsed up to 6 times with ultrapure water prior to dissolution. Lead separation was then performed on an anionic exchange resin. High-resolution $\mathrm{Pb}$ isotopic analyses were carried out on a VG sector 54 multi-collector instrument, using the double spike technique with the calibrated Southampton-Brest ${ }^{207} \mathrm{~Pb} /{ }^{204} \mathrm{~Pb}$ spike (Ishizuka et al., 2003). The true $\mathrm{Pb}$ isotopic compositions were obtained from the natural and mixture runs by iterative calculation adopting a modified linear mass bias correction (Johnson and Beard, 1999). The reproducibility of this Pb isotopic measurement (external error: $2 \sigma$ ) by double spike is $<200 \mathrm{ppm}$ for all ${ }^{20 x} \mathrm{~Pb} /{ }^{204} \mathrm{~Pb}$ ratios. Measured values for NBS SRM-981 during the measurement period were ${ }^{206} \mathrm{~Pb} /{ }^{204} \mathrm{~Pb}=16.9414 \pm 26, \quad{ }^{207} \mathrm{~Pb} /{ }^{204} \mathrm{~Pb}=15.4997 \pm 30$ and ${ }^{208} \mathrm{~Pb} /{ }^{204} \mathrm{~Pb}=36.726 \pm 9(2 \sigma, n=9) . \mathrm{Pb}$ blanks measured using this procedure were $<100 \mathrm{pg}$, and thus negligible relative to the amount of sample analysed.

\section{Geological setting and K-Ar ages}

\subsection{Geological and tectonic framework}

The geology of the Republic of Djibouti records the effects of the activity of the Afar mantle plume since 30 Ma (Schilling, 1973; Barberi et al., 1975; Barberi and Varet, 1977; 
138 Furman et al., 2006). Plume-related basaltic and derived magmas, variably enriched in incompatible elements (e.g., Joron et al., 1980; Deniel et al., 1994) cover ca. 90\% of its surface, and range in age from at least $23.6 \pm 0.5 \mathrm{Ma}$ to Present (Barberi et al., 1975;

141 Courtillot et al., 1984; Zumbo et al., 1995). Since the Miocene, the most salient tectonomagmatic process observed in the area was the penetration of the Gulf of Aden (GA) oceanic ridge between the Arabia and Somalia plates, hence leading to the opening of the Tadjoura Gulf (Courtillot et al., 1980; Manighetti et al., 1997), at the southwestern edge of which the emerged Asal Rift shows spectacular evidence for both tectonic and magmatic activities (Stieltjes et al., 1976; Needham et al., 1976).

Onland, the principal marker of the Pliocene opening of the Tadjoura Gulf (TG) was the emplacement of a $<350 \mathrm{~m}$-thick basaltic lava flow pile, referred to as the "initial basaltic series from the borders of the Tadjoura Gulf" (Fournier et al., 1982; Gasse et al., 1983), which will be named hereafter the Tadjoura Gulf Basalts (TGB). These very fluid subaerial lava flows are generally assumed to have been emitted from now submerged fissures in the Gulf, and emplaced rather symmetrically outwards on the twin margins (Fig. 1, inset) (Richard, 1979). Additional feeder dykes, and associated neck-like features, have been identified onshore, along the northern flank in the Tadjoura area. TGB range from olivine tholeiites to ferrobasalts, and in thin section are subaphyric to sparsely phyric, with 3-6 modal\% calcic plagioclase, and 1-3 modal\% olivine set in a microlitic groundmass. They display mild, but significant, enrichments in light rare earth elements (LREE) and other highly incompatible elements (Joron et al., 1980; Barrat et al., 1990, 1993; Deniel et al., 1994).

In the Djibouti plain, the TGB are involved in a coastal network of Gulf-parallel tilted fault blocks, bounded by dominantly extensional $\mathrm{N}$-facing structures, in association with $\mathrm{N} 140^{\circ} \mathrm{E}$ normal faults outlined by a swarm of small cinder cones (Fig. 1). To the East, they are post-dated by the Hayyabley elongated volcano, the long axis of which also strikes NWSE, parallel to the regional fault scarp bounding the eastern coastal plain further SE.

\subsection{The Hayyabley volcano}

The youngest volcanic units in the Djibouti plain are a set of generally small (less than $100 \mathrm{~m}$ high) ash and cinder strombolian-type cones with associated basaltic flows (e.g. the Nagâd volcano, Fig. 1), aligned along a young NNW-SSE fracture network (Fournier et al., 1982). They overlie the TGB and have been dated to 1.75-1.70 Ma (Gasse et al., 1983). The largest of these post-TGB volcanic centers is the Hayyabley volcano, east of Djibouti town 
172 (Fig. 1). Although it was shown on the 1:50 000 geological map of Djibouti (Fournier et al., 173 1982), and further well-described and dated by Gasse et al. (1983), it was apparently never

174

175

176

177

178

179

180

181

182

183

184

185

186

187

188

189

190

191

192

193

194

195

196

197

198

199

200

201

202

203

investigated later despite the obviously unusual characteristics of its basaltic lavas.

The Hayyabley volcano in map-view is a $5 \times 10 \mathrm{~km}$ elliptic edifice, with a NNW-SSE trending axis. It has a shield-like and rather flat morphology, and culminates at $147 \mathrm{~m}$ at Signal Bouêt. It overlies the TGB lava flows outcropping W and N of Wadi Ambouli valley (Fig. 1), and seals the EW to WNW-ESE normal fault pattern related to the Tadjoura rift. Despite the rather large aerial extent of its lavas, we estimate its volume to ca. $0.6-0.8 \mathrm{~km}^{3}$ only. Its eruptive vents are no longer identifiable, possibly because of the strong anthropic imprint and constructions of the Djibouti suburbs: they are thought to be located in its summit zone, and aerial photograph data suggest radial emplacement of the lava flows away from this summit (Fournier et al., 1982).

The total thickness of the Hayyabley lava flow pile is estimated at $120 \mathrm{~m}$. The best section is exposed in Wadi Warabor, along the northern coast (Fig. 1). There, we sampled seven superimposed basaltic lava flows (DJ54B to DJ54H), resting conformably upon a 15 mthick columnar-jointed lava flow (DJ54A) belonging to the TGB sequence. These flows are vesicle-rich, and their thickness decreases upwards from ca. $4 \mathrm{~m}$ to less than $20 \mathrm{~cm}$. Only the thickest lava flows show columnar jointing, and the uppermost ones are highly vesicular and often scoriaceous (Gasse et al., 1983). A sample (TF 914) collected from a possible eruption vent in the summit area had been dated by the K-Ar unspiked method to $0.98 \pm 0.10 \mathrm{Ma}$ and $0.83 \pm 0.08 \mathrm{Ma}$ (Gasse et al., 1983), the youngest K-Ar dates obtained so far in the area. We have checked the previous results by dating two basaltic flows from the Wadi Warabor section (Fig. 1). The results are shown in Table 1. The two ages obtained, $0.93 \pm 0.06 \mathrm{Ma}$ and $1.06 \pm 0.09 \mathrm{Ma}$, are mutually consistent, and compatible as well with those previously published (Gasse et al., 1983). Indeed, the four results almost overlap at around $0.91-0.97$ $\mathrm{Ma}$, and are remarkably convergent considering the very low concentration of potassium in the studied samples and the young age range.

\section{Petrologic and geochemical results}

\subsection{Petrographic and mineralogical features}


The Hayyabley basalts are rather homogeneous from a petrographic point of view, and also quite different from the underlying TGB. They are moderately to highly vesicular (10 to 30 modal\% vesicles in thin section). These vesicles are usually empty, or sometimes partly filled by calcite, especially in the summit part of the volcano. The rocks are also sparsely to moderately phyric, with 5 to 15 modal\% phenocrysts, the size of which ranges from 0.5 to 3 mm. They include olivine (dominant) and calcic plagioclase (subordinate), in a roughly 2:1 ratio. These phenocrysts are set in a holocrystalline groundmass, showing doleritic or intersertal textures. It contains, by order of decreasing abundance, plagioclase laths, olivine microcrysts (the periphery of which is often replaced by iddingsite), calcic pyroxene grains and titanomagnetite.

Olivine compositions range from $\mathrm{Fo}_{84-82}$ for the phenocryst cores to $\mathrm{Fo}_{78-54}$ for their rims and the microcrysts, the smallest ones being the most Fe-rich. The plagioclase phenocryst cores are bytownitic $\left(\mathrm{An}_{86-77}\right)$ and contain negligible amounts of Or component $(<0.3 \%)$. The corresponding rims are less calcic $\left(\mathrm{An}_{70-32}\right)$ and the small laths from the groundmass are clearly enriched in alkalis (up to $\mathrm{An}_{27-15} \mathrm{Ab}_{70-80} \mathrm{Or}_{2-5}$ ). Groundmass clinopyroxenes are augitic $\left(\mathrm{Wo}_{45-41} \mathrm{En}_{43-40} \mathrm{Fs}_{12-16}\right)$ and their low $\mathrm{TiO}_{2}(<1 \mathrm{wt} \%)$ and $\mathrm{Na}_{2} \mathrm{O}(<0.3 \mathrm{wt} \%)$ contents are typical of tholeiitic clinopyroxenes.

\subsection{Major and trace elements on bulk rocks}

Nine samples taken from different flows from four locations (Fig. 1) were analysed, and the results are given in Table 2. Their major and trace element abundances are rather uniform. These lavas display high $\mathrm{Al}_{2} \mathrm{O}_{3}(16.4-17.05 \mathrm{wt} \%)$ and $\mathrm{CaO}$ (12.5-13.8 wt\%) abundances, low $\mathrm{Na}_{2} \mathrm{O}(1.9-2.1 \mathrm{wt} \%$ ) abundances and $\mathrm{FeO} * / \mathrm{MgO}$ ratios close to 1 . Although not primitive, these lavas are amongst the least evolved basalts collected so far from the Republic of Djibouti. Indeed, they exhibit the highest compatible trace element abundances (e.g., Ni, Co, Cr) measured in samples from this area (e.g., Joron et al., 1980; Barrat et al., 1990, 1993; Deniel et al., 1994).

More importantly, their incompatible trace element abundances are low, and these samples are characterized by light REE depletions $\left(\mathrm{La}_{\mathrm{n}} / \mathrm{Sm}_{\mathrm{n}}=0.76-0.83\right)$, and small but significant positive $\mathrm{Eu}$ anomalies $\left(\mathrm{Eu} / \mathrm{Eu}^{*}=1.08-1.12\right.$, Fig. 2). These features unambiguously distinguish the Hayyabley basalts from both the TGB and the older post-TGB basalts, which are always LREE-enriched (Joron et al., 1980; Barrat et al., 1990, 1993; Deniel et al., 1994). 
The unusual features of the Hayyabley basalts are strengthened by their primitive mantle normalised patterns that exhibit large positive $\mathrm{Ba}\left(\mathrm{Ba}_{\mathrm{n}} / \mathrm{Rb}_{\mathrm{n}}=2.9-8.6\right)$ and $\mathrm{Sr}\left(\mathrm{Sr}_{\mathrm{n}} / \mathrm{Ce}_{\mathrm{n}}=1.8-2.1\right)$ anomalies (Fig. 3). Although LREE-depleted, the Hayyabley basalts are clearly distinct from typical N-MORB and basalts erupted by the nearby nascent oceanic ridges. For example, basalts with $\mathrm{N}$ to T-MORB affinities are known from the eastern part of the Tadjoura Gulf (Barrat et al., 1990, 1993). Although a positive Sr anomaly has been observed in a single LREE-depleted basalt, positive $\mathrm{Ba}$ and Eu anomalies are missing (Barrat et al., 1990, 1993 and unpublished results). In addition, the $\mathrm{Nb} / \mathrm{Y}$ and $\mathrm{Zr} / \mathrm{Y}$ ratios (0.11-0.15 and 2.20-2.57, respectively, Table 2) of Hayyabley basalts are such that these lavas plot within the field of Icelandic plume basalts, and well above the N-MORB field, in Fitton et al.'s $(1997,2003)$ rectangular plot (not shown).

Interestingly, the Hayyabley basalts are remarkably similar to the scarce LREE-depleted basalts which were sporadically emitted by the Manda Hararo rift, Ethiopia (Barrat et al., 2003). Indeed, the latter display incompatible element abundances and distributions very similar to those of the Hayyabley basalts (Fig. 3). The noticeable differences are minor. The Manda Hararo basalts are somewhat more evolved than the Hayyabley basalts and have for example lower $\mathrm{Ni}$ and $\mathrm{Cr}$ concentrations (Table 3). In addition, an Oligocene basaltic flow with the same features (sample E88) was reported by Pik et al. (1999) from the Ethiopian Plateau.

\section{3. $\mathrm{Sr}, \mathrm{Nd}, \mathrm{Pb}$ isotopic data}

The isotopic compositions of five samples are given in Table 4, and are almost uniform, with the exception of ${ }^{87} \mathrm{Sr} /{ }^{86} \mathrm{Sr}$ ratios which vary significantly in the range $0.70369-0.70396$

262 (Table 4). Although relatively fresh, the Hayyabley basalts display some evidence of weathering. One may suspect that their ${ }^{87} \mathrm{Sr} /{ }^{86} \mathrm{Sr}$ ratios are not pristine, and have been affected by secondary processes. Indeed, the least radiogenic sample DJ59 displays a negative Loss On Ignition (LOI) value (-0.38 wt\%). Conversely, the LOI value of the most radiogenic sample (DJ54H) is much higher $(0.92 \mathrm{wt} \%)$, and in a ${ }^{87} \mathrm{Sr} /{ }^{86} \mathrm{Sr}$ vs. LOI plot (not shown), a weak positive correlation is apparent. In order to check if the $\mathrm{Sr}$ isotopic compositions of the samples were modified by alteration, $150 \mathrm{mg}$ of sample DJ54B was leached for 2 hours in hot $\left(150^{\circ} \mathrm{C}\right) 6 \mathrm{~N} \mathrm{HCl}$, and rinsed in deionized water prior to dissolution. Its ${ }^{87} \mathrm{Sr} /{ }^{86} \mathrm{Sr}$ ratio is significantly lower than the value obtained on the unleached powder (Table 4), a result which 
suggests that the Sr isotopic compositions have been modified by secondary processes.

272 Similar observations were made by Deniel et al. (1994) on other samples from Djibouti. Thus,

${ }^{87} \mathrm{Sr} /{ }^{86} \mathrm{Sr}$ obtained on unleached samples from this area should be discussed only with extreme caution, even ratios obtained from apparently fresh basalts. We believe that only two ${ }^{87} \mathrm{Sr} /{ }^{86} \mathrm{Sr}$ measurements can be safely used in the discussion: the least radiogenic one (DJ59), and the value obtained on the leached residue of DJ54B.

The $\mathrm{Sr}, \mathrm{Nd}$, and $\mathrm{Pb}$ isotopic compositions of the Hayyabley basalts are compared to those of other volcanics from the Horn of Africa in figures 4 to 6. In these plots, Hayyabley basalts lie significantly outside the fields defined by the submarine basalts erupted from the nascent oceanic ridges of the Red Sea, the Eastern part of the Tadjoura Gulf, and the Aden Gulf. These features indicate that these LREE-depleted lavas are unlike MORB (Figs. 5 and 6). For example, they display ${ }^{87} \mathrm{Sr} /{ }^{86} \mathrm{Sr}$ ratios more radiogenic than N-MORB, and significantly lower $\varepsilon_{\mathrm{Nd}}$ values (Ito et al., 1987). In contrast, the $\varepsilon$ Nd vs. ${ }^{87} \mathrm{Sr} /{ }^{86} \mathrm{Sr}$ plot (Fig. 4) shows that the Hayyabley basalts and LREE-depleted basalts from Manda Hararo are isotopically very similar. The Hayyabley basalts display almost uniform $\mathrm{Pb}$ isotopic compositions $\left({ }^{206} \mathrm{~Pb} /{ }^{204} \mathrm{~Pb}=18.47-18.55,{ }^{207} \mathrm{~Pb} /{ }^{204} \mathrm{~Pb}=15.52-15.57,{ }^{208} \mathrm{~Pb} /{ }^{204} \mathrm{~Pb}=38.62-38.77\right)$ well above the NHRL (Hart, 1984, 1988; see Table 4). In the Sr-Nd, Pb-Pb and Nd-Pb plots (Figs. 4 to 6), the Hayyabley basalts extend the range of the compositions displayed by the young $(<4 \mathrm{Ma})$ basalts from Djibouti. They might reflect the contribution of a distinct LREE component in their petrogenesis.

\section{Discussion}

Although Ethiopian Plateau basalts (Pik et al., 1999; Kieffer et al., 2004; Meshesha and Shinjo, 2007; Beccaluva et al., 2009), and Afar basalts (Treuil and Joron, 1975; Joron et al., 1980; Deniel et al., 1994) are dominantly enriched, previous studies (Barrat et al., 1993, 2003; Pik et al., 1999; Meshesha and Shinjo, 2007) have demonstrated that minor depleted components were also involved in their petrogenesis. The discovery of a new occurrence of LREE-depleted basalts in Djibouti, i.e. further east in the Afar rift setting, might provide new constrains on their origin. Two main points will be discussed below: (1) the origin of the Ba, Sr and Eu positive anomalies observed in the Hayyabley basalts, and (2) the occurrence of a specific LREE-depleted component in the sources of the Afar basalts. 
The origin of $\mathrm{Ba}, \mathrm{Sr}$ and $\mathrm{Eu}$ positive anomalies in LREE-depleted basalts has been previously investigated in the cases of some Icelandic basalts (e.g., Kokfelt et al., 2006 and references therein) and of the Manda Hararo basalts (Barrat et al., 2003). The compositions of LREE-depleted basalts such as those erupted by the Hayyabley volcano might be related to those of common MORB. The chief differences between them could be due to secondary processes, such as hot-desert weathering, crystal accumulation, or contamination by a crustal component. Alternatively, they could be derived from an unusual mantle source, located in the lithospheric or asthenospheric mantle or in the plume itself.

In a hot-desert environment, surface processes are able to generate positive $\mathrm{Ba}$ and $\mathrm{Sr}$ anomalies in a very short time. The studies of meteorites from Sahara have demonstrated that some of them, and not only the most weathered ones, exhibit marked $\mathrm{Ba}$ and Sr enrichments that are sensitive indicators of the development of secondary calcite, gypsum, or barytes (e.g., Barrat et al., 1998, 2003). Such processes would have generated a range of $\mathrm{Ba}$ and $\mathrm{Sr}$ abundances from low values typical of unweathered N-MORB (about $10 \mathrm{ppm} \mathrm{Ba}$ and 100 ppm Sr) to much higher concentrations. However, $\mathrm{Ba}$ and $\mathrm{Sr}$ abundances in the Hayyabley basalts are uniform, and strikingly similar to the concentrations measured in the distant Manda Hararo basalts. Furthermore, the development of secondary phases is unable to increase the $\mathrm{Eu} / \mathrm{Eu}^{*}$ ratio and to generate positive $\mathrm{Eu}$ anomalies, hence ruling out this first explanation.

Positive $\mathrm{Ba}, \mathrm{Sr}$ and $\mathrm{Eu}$ anomalies in basaltic rocks are usually explained by plagioclase accumulation or assimilation. However this process is unable to produce $\mathrm{Sr}$ anomalies as high as those displayed by the Hayyabley or Manda Hararo basalts without increasing drastically the $\mathrm{Al}_{2} \mathrm{O}_{3}$ contents of the resulting rocks. The fact that the $\mathrm{Al}_{2} \mathrm{O}_{3}$ abundances of the LREEdepleted basalts are not anomalously high (Table 2) is inconsistent with the hypothesis of plagioclase accumulation. Assimilation of plagioclase-rich gabbros from the oceanic lithosphere during ascent of plume-related magmas has been proposed in the cases of offshore Tadjoura Gulf basalts (Barrat et al., 1993) and Galapagos basalts (Saal et al., 2007). However, reproducing the compositions of Hayyabley basalts through this process, and especially their positive $\mathrm{Ba}, \mathrm{Sr}$ and $\mathrm{Eu}$ anomalies, would require rather high rates of assimilation. In addition, the Hayyabley and Manda Hararo basalts overlie thinned continental crust which is $25-26 \mathrm{~km}$ thick (Dugda and Nyblade, 2006), while the depleted plateau basalt sample E88 (Pik et al., 1999) is located on normal (ca. $40 \mathrm{~km}$ thick) African crust. Due to the presence of a 
crustal or even subcrustal depths of associated gabbroic cumulates. However, these gabbros should be LREE-enriched like the vast majority of Afar basalts. Therefore, their interaction with depleted (N-MORB type) melts is likely to lead to variably LREE-enriched magmas with isotopic compositions close to those of the flood basalts.

The Hayyabley basalts have radiogenic $\mathrm{Sr}$ isotopic compositions and low $\varepsilon \mathrm{Nd}$ values relative to Aden Gulf or Red Sea MORBs (Schilling et al., 1992; Volker et al., 1993; Hase et al., 2000). The assimilation of a continental component could explain this shift from usual NMORB values, but incompatible trace element ratios give no support to this interpretation. Contamination of MORB-like melts by continental crust would produce significant changes in incompatible trace element ratios. The Hayyabley basalts, like the Manda Hararo LREEdepleted basalts, lack the negative $\mathrm{Nb}$ or $\mathrm{Ta}$ anomalies observed in the multi-element plots of crust-contaminated basalts. Moreover, they show a limited range of $\mathrm{Ce} / \mathrm{Pb}$ ratios from 24 to 28, similar to values measured in oceanic basalts (e.g., Sun and McDonough, 1989). Therefore, there is no indication for assimilation of significant amounts of material derived from the continental crust in the LREE-depleted basalts. In the case of the Manda Hararo basalts, this conclusion is strengthened by their $\delta^{18} \mathrm{O}$ values close to $5.5 \%$, which are typical of mantle composition (Barrat et al., 2003).

Another possible explanation of the specific features of Hayyabley and Manda Hararo basalts is that they might result from the interaction between ascending depleted (N-MORB type) melts and the African subcontinental lithospheric mantle. Once again, such a mantle is expected to be LREE-enriched (Hart et al., 1989; Vidal et al., 1991; Deniel et al., 1994) and thus should transmit its trace element and isotopic fingerprint to LREE-poor ascending magmas. In addition, the remarkably similar chemical features of Hayyabley, Manda Hararo and E88 basalts suggest that they derive from almost identical sources and petrogenetic processes. Their distinct locations, emplacement ages (Oligocene for E88, ca. 1 Ma for Hayyabley and less than $0.2 \mathrm{Ma}$ for Manda Hararo) and underlying crustal/lithospheric thickness (normal for E88, thinned for the two other occurrences) are hardly consistent with a similar petrogenetic history.

Therefore, as previously pointed out for the Manda Hararo basalts (Barrat et al., 2003), the positive $\mathrm{Sr}, \mathrm{Ba}$ and $\mathrm{Eu}$ anomalies and the particular $\mathrm{Sr}-\mathrm{Nd}-\mathrm{Pb}$ isotopic features of the Hayyabley basalts, are more likely a genuine feature inherited from their deep mantle sources. The same conclusions have been reached for depleted basalts with similar positive anomalies from Iceland. Chauvel and Hémond (2000), Skovgaard et al. (2001), and Kokfelt et al. (2006) have suggested that the sources of Icelandic lavas contained an old recycled oceanic 
373 lithosphere component and that melting of the gabbroic portion of this lithosphere led to the

374 formation of basalts that exhibit large positive $\mathrm{Ba}, \mathrm{Sr}$ and $\mathrm{Eu}$ anomalies. At first glance, such 375 an explanation is attractive because if this recycled gabbroic component has been 376 hydrothermally altered, one may expect ${ }^{87} \mathrm{Sr} /{ }^{86} \mathrm{Sr}$ ratios much more radiogenic than those of 377 typical MORB. Hence, the involvement of such component could account for the relatively 378 high ${ }^{87} \mathrm{Sr} /{ }^{86} \mathrm{Sr}$ ratios of the Manda Hararo and Hayyabley depleted basalts. However, an old 379 LREE-depleted recycled gabbroic component from the oceanic lithosphere would also be 380 characterized by high $\varepsilon_{\mathrm{Nd}}$ values. On the contrary, the Manda Hararo and Hayyabley lavas 381 display $\varepsilon_{\mathrm{Nd}}$ values unexpectedly low $\left(\varepsilon_{\mathrm{Nd}}=5-7\right)$ for depleted basalts. Thus, we conclude that, 382 at best, this model only partially fits the observations.

\subsection{The depleted components in the sources of Djibouti and Ethiopian basalts}

385

Previous geochemical studies have demonstrated the participation of a depleted component during the genesis of the Horn of Africa basalts. In the case of basalts emitted by the young oceanic ridges from the Red Sea or the Aden Gulf, major involvement of MORBrelated sources has been proposed (e.g., Barrat et al., 1990, 1993; Schilling et al., 1992; Volker et al., 1993). These submarine basalts do not have the unradiogenic $\mathrm{Pb}$ isotopes of the Carslberg Ridge ca. $1600 \mathrm{~km}$ east of Hayyabley volcano (Hart, 1984) but do extend away from the Indian Ocean MORB toward a more HIMU composition. On land, huge volumes of enriched basalts were emplaced in Afar and Ethiopia. The trace element and isotopic features of the depleted reservoirs which have been involved during the genesis of the scarce LREEdepleted lavas are very difficult to constrain. Two distinct LREE-depleted components have been unambiguously detected.

First, a depleted MORB mantle component is clearly involved in the genesis of Quaternary basalts from Northern Afar. The $\mathrm{Sr}-\mathrm{Nd}-\mathrm{Pb}$ isotopic relationships displayed by the Erta'Ale basalts (Figs. 4 to 6) point to the participation of two mantle end-members, namely a HIMU component and a depleted mantle (DM) component undistinguishable from the source of the Red Sea MORB (Barrat et al., 1998). Furthermore, a similar depleted component has been detected in the sources of the Oligocene lavas from the Northwestern Ethiopian volcanic province (Meshesha and Shinjo, 2007). The entrainment of depleted asthenospheric mantle during plume ascent (Furman et al., 2006) is a possible explanation for the contribution of this component to the sources of some of the basalts erupted in Afar and Ethiopia, as well as to those of Kerguelen basalts (Doucet et al., 2002). However, numerical models (Farnetani et al., 
2002; Farnetani and Samuel, 2005) suggest that incorporation of depleted upper mantle within ascending plumes is unlikely to occur.

In addition, the compositions of LREE-depleted basalts from Hayyabley and Manda Hararo point to a depleted end-member chemically (Fig. 3) and isotopically (Figs. 4 to 6) distinct from an asthenospheric MORB-like component. A single Oligocene LREE-depleted basalt displaying chemical features similar to those of the Quaternary depleted ones has been collected in Ethiopia (sample E88, Pik et al., 1999). Although its isotopic composition is slightly different from those of the Hayyabley basalts (Figs. 4 to 6), the occurrence of this sample indicates that a depleted component distinct from the MORB source was involved in this area at an early stage of plume emplacement. Therefore, we suggest that a depleted component, intrinsic to the plume at depth, has contributed to the sources of both young and old lavas related to the Afar plume. Similar conclusions have been reached for the Hawaiian (Frey et al., 2005) and Icelandic (Thirlwall, 1995; Kerr et al., 1995; Fitton et al., 1997; Chauvel and Hémond, 2000; Thirlwall et al., 2004; Skovgaard et al., 2001; Kokfelt et al., 2006) plumes. However, the nature of this component is currently difficult to constrain in the Afar case. Indeed, melting of the gabbroic part of an old recycled oceanic lithosphere (e.g., Kokfelt et al., 2006) would produce high $\varepsilon_{\mathrm{Nd}}$ magmas and therefore this process does not account for the low $\varepsilon_{\mathrm{Nd}}$ values of Hayyableh and Manda Hararo basalts. Alternatively, LREE depletion could be due to a previous melting event affecting the plume materials, as proposed by Thirlwall et al. (2004) for their ID2 (or RRD2) depleted component of the Icelandic plume. This hypothesis may account for the $\mathrm{Pb}$ isotopic differences between Hayyabley/Manda Hararo basalts and the other (enriched) Djibouti basalts (Figs. 4 to 6) but can hardly explain the higher Sr isotopic ratios of Hayyabley and Manda Hararo basalts.

Finally, another intriguing problem is the causal mechanism for the sporadic eruption of small volumes of such nearly pure "depleted" melts in spatially and temporally distinct locations, without any significant contamination by the dominant enriched materials. Indeed, such features are difficult to reconcile with models postulating a large concentrically-zoned Afar plume (e.g., Beccaluva et al., 2009). Numerical simulations of the evolution of thermal and thermo-chemical plumes (Farnetani et al., 2002; Farnetani and Samuel, 2005; Farnetani and Hofmann, 2009) suggest that small heterogeneous mantle domains present in the thermal boundary layer feeding the plume are converted, during the ascent of the latter, into long-lived elongated and narrow filaments within the plume conduit. Such filaments would melt sporadically, and then eventually communicate their specific geochemical fingerprint to small volumes of basaltic lavas (Farnetani and Hoffmann, 2009). 


\section{Conclusions}

The 1 Ma-old Hayyabley volcano (SE Djibouti) has emitted ca. $0.6-0.8 \mathrm{~km}^{3}$ of LREE-depleted basalts $\left(\mathrm{La}_{\mathrm{n}} / \mathrm{Sm}_{\mathrm{n}}=0.76-0.83\right)$ that display unusual chemical features (positive $\mathrm{Ba}, \mathrm{Sr}$ and $\mathrm{Eu}$ anomalies). These lavas are chemically distinct from the N-MORBs erupted from the nearby Red Sea and Gulf of Aden oceanic ridges, and instead closely resemble the LREE-depleted basalts from the Manda Hararo rift in Central Afar (Barrat et al., 2003). Another similar occurrence, Oligocene in age, has been reported from the trap series in the Ethiopian Plateau by Pik et al. (1999). Our new results confirm the presence within the Afar region of basalts derived from an uncommon depleted component, isotopically distinct from the source of the Red Sea MORBs and from the similarly depleted mantle (DM in Figs. 4 to 6) which contributes to the genesis of Erta'Ale volcanics (Barrat et al., 1998). This component

454 is not unusual from an isotopic $(\mathrm{Sr}, \mathrm{Nd}, \mathrm{Pb}, \mathrm{O})$ point of view, and is mainly recognizable from the specific trace element signature of the corresponding basalts (positive $\mathrm{Ba}, \mathrm{Sr}, \mathrm{Eu}$ anomalies combined with LREE depletion).

The origin of the Hayyabley-Manda Hararo basalts fingerprint could be ascribed to the interactions between (i) depleted (N-MORB type) basalts derived from an asthenospheric mantle component similar to the Erta 'Ale depleted end-member and (ii) enriched lithospheric materials which would be responsible for the positive $\mathrm{Ba}, \mathrm{Sr}$ and $\mathrm{Eu}$ anomalies. These materials could be either the African continental crust, flood basalt-related gabbroic cumulates stored within or below it, or finally the subcontinental lithospheric mantle. Hovever, all these materials are mostly LREE-enriched, and the contamination hypothesis can hardly explain the clear LREE, $\mathrm{Rb}$ and $\mathrm{Th}$ depletion and concomitant $\mathrm{Ba}, \mathrm{Sr}$ and $\mathrm{Eu}$ enrichment of Hayyabley basalts (Figs. 2 and 3) as well as their Pb isotopic signature (Figs. 5 and 6). Moreover, contamination in plume-related volcanic series is often described as a variable, occasional or random process. Thus, it can hardly account for the very specific trace element and isotopic signature of the Afar depleted basalts, which were erupted in three separate locations, with distinct emplacement ages and underlying crustal/lithospheric thickness.

Therefore, our preferred conclusion is that these depleted basalts derive from a intrinsic (although volumetrically minor) depleted component from the Afar plume, possibly present as elongated and narrow filaments within the plume conduit. Sporadic melting of such filaments 
might account for the restricted spatial and temporal distribution of the Afar depleted basalts. The precise origin of this deep mantle component is currently difficult to constrain, given the small number of depleted basalt samples and the limited amount of corresponding geochemical data. The most likely hypothesis is the contribution of recycled gabbros from ancient oceanic crust.

\section{Acknowledgements}

This study has been funded by the French Embassy in Djibouti, and the grant of the first author (M.A.D.) provided by the MAWARI international program managed by the CIFEG, Orléans, France. Analytical expenses were funded by the MAWARI program and UMR 6538, Plouzané. We especially thank Dr. Mohamed Jalludin, Director of the CERD, for his interest, scientific discussions and logistic support, Ali Abdillahi for his efficiency in organizing fieldwork, and Marcel Bohn for his help with microprobe analysis. Careful reviews by Tania Furman and Godfrey Fitton led us to improve significantly the organization and contents of this manuscript.

\section{References}

Baker, J.A., Thirlwall, M.F., Menzies, M.A., 1996. Sr-Nd-Pb isotopic and trace element evidence for crustal contamination of plume-derived flood basalts: Oligocene flood volcanism in Western Yemen. Geochimica et Cosmochimica Acta 60, 2559-2581.

Barberi, F., Ferrara, G., Santacroce, R., Varet, J., 1975. Structural evolution of the Afar triple junction. In: Pilger, A., Rösler, A., (Eds.) Afar Depression of Ethiopia. Schweizerbart, Stuttgart, 38-54.

Barberi, F., Varet, J., 1977. Volcanism in Afar, small scale plate tectonics implications. Geological Society of America Bulletin 88, 1251-1266.

Barrat, J.A., Keller, F., Amossé, J., Taylor, R.N., Nesbitt, R.W., Hirata, T., 1996. Determination of rare earth elements in sixteen silicate reference samples by ICP-MS after Tm addition and ion exchange separation. Geostandards Newsletter 20, 133-139.

Barrat, J.A., Fourcade, S., Jahn, B.M., Cheminée, J.L., Capdevila, R., 1998. Isotope (Sr, Nd, $\mathrm{Pb}, \mathrm{O})$ and trace-element geochemistry of volcanics from the Erta'Ale range (Ethiopia). Journal of Volcanology and Geothermal Research 80, 85-100. 
Barrat, J.A, Jahn, B.M., Joron, J.L., Auvray, B., Hamdi, H., 1990. Mantle heterogeneity in northeastern Africa: evidence from $\mathrm{Nd}$ isotopic compositions and hygromagmaphile element geochemistry of basaltic rocks from the Gulf of Tadjoura and Southern Red Sea regions. Earth and Planetary Science Letters 101, 233-247.

Barrat, J.A., Jahn, B.M., Fourcade, S., Joron, J.L., 1993. Magma genesis in an ongoing rifting zone: the Tadjoura Gulf. Geochimica et Cosmochimica Acta 57, 2291-2302.

Barrat, J.A., Blichert-Toft, J., Gillet, P., Keller, F., 2000. The differentiation of eucrites: the role of in situ crystallization. Meteoritics \& Planetary Science 35, 1087-1100.

Barrat, J.A., Joron, J.L., Taylor, R.N., Fourcade, S., Nesbitt, R.W., Jahn, B.M., 2003. Geochemistry of basalts from Manda Hararo, Ethiopia: LREE-depleted basalts in Central Afar. Lithos 69, p. 1-13.

Barrat, J.A., Yamaguchi, A., Greenwood, A., Bohn, M., Cotten, J., Benoit, M., Franchi, I.A., 2007. The Stannern trend eucrites: contamination of main group eucritic magmas by crustal partial melts. Geochimica et Cosmochimica Acta 71, 4108-4124.

Beccaluva, L., Bianchini, G., Natali, C., Siena, F., 2009. Continental flood basalts and mantle plumes: a case study of the Northern Ethiopian Plateau. Journal of Petrology 50, 1377-1403.

Blichert-Toft, J., White, W.M., 2001. Hf isotope geochemistry of the Galapagos Islands. Geochemistry, Geophysics, Geosystems 2, doi:10.129/2000GC000138.

Charbit, S., Guillou, H., Turpin, L., 1998. Cross calibration of K-Ar standard minerals using trace element and $\mathrm{Pb}$ isotopic evidence from Iceland. Geochemistry, Geophysics, Geosystems 1, paper number 1999GC000002. 
Chen, C.-Y., Frey, F.A., 1985. Trace element and isotope geochemistry of lavas from Halaakala Volcano, East Maui: implications for the origin of Hawaiian basalts. Journal of Geophysical Research 90, 8743-8768. M., Brousse, R., 1995. Origin of anomalous rare-earth element and yttrium enrichments in subaerially exposed basalts: Evidence from French Polynesia.

Courtillot, V., Galdeano, A., Le Mouel, J.-L., 1980. Propagation of an accreting plate Chemical Geology 119, 115-138. boundary: a discussion of new magnetic data in the Gulf of Tadjoura and Southern Afar.

Courtillot, V., Achache, J., Landre, F., Bonhommet, N., Montigny, R., Féraud, G., 1984. Episodic spreading and rift propagation: new paleomagnetic and geochronologic data from the Afar nascent passive margin. Journal of Geophysical Research 89, 3315-3333.

Daoud, M.A., 2008. Dynamique du rifting continental de 30 Ma à l'Actuel dans la partie sud-est du Triangle Afar. Tectonique et magmatisme du rift de Tadjoura et des

Defant, M.J., Maury, R.C., Ripley, E.M., Feigenson, M.D., Jacques, D., 1991. An example domaines Danakil et d'Ali Sabieh, République de Djibouti. Thèse, Université de Bretagne Occidentale, Brest, 190 p. of island-arc petrogenesis: geochemistry and petrology of the southern Luzon arc, Philippines. Journal of Petrology 32, 455-500. Atlantic Ridge, $10^{\circ}-24^{\circ} \mathrm{N}$ : trace element-isotope complementary. Earth and Planetary Science Letters 120, 443-462. 
Doucet, S., Weis, D., Scoates, J.S., Nicolaysen, K., Frey, F.A., Giret, A., 2002. The depleted mantle component in Kerguelen Archipelago basalts: petrogenesis of tholeiitictransitional basalts from the Loranchet Peninsula. Journal of Petrology 43, 1341-1366.

Dugda, M.T., Nyblade, A.A., 2006. New constraints on crustal structure in eastern Afar 582 from the analysis of receiver functions and surface wave dispersion in Djibouti. In: Yirgu, G., Ebinger, C.J., Maguire, P.K.H., (Eds.), The Afar volcanic province within the

Evensen, N.M., Hamilton, P.J., O'Nions, R.K., 1978. Rare Earth abundances in chondritic 589

Farnetani, C.G., Legras, B., Tackley, P.J., 2002. Mixing and deformation in mantle plumes. 592

Farnetani, C.G., Samuel, H., 2005. Beyond the thermal plume paradigm. Geophysical 594 595 Earth and Planetary Science Letters, 196, 1-15.

Fitton, J.G., Saunders, A.D., Norry, M.J., Hardason, B.S., Taylor, R.N., 1997. Thermal and 600 601 chemical structure of the Iceland plume. Earth and Planetary Science Letters, 153, $197-$ 602

Farnetani, C.G., Hofmann, A.W., 2009. Dynamics and internal structure of a lower mantle plume conduit. Earth and Planetary Science Letters, 282, 314-322. 
Fournier, M., Gasse, F., Lépine, J.-C., Richard O., Ruegg J.C., 1982. Carte géologique de la République de Djibouti à 1:100 000. Djibouti. ISERST. Ministère français de Coopération. Ed. ORSTOM, Paris.

Frey, F.A., Huang, S., Blichert-Toft, J., Regelous, M., Boyet, M., 2005. Origin of depleted components in basalt related to the Hawaiian hot spot: Evidence from isotopic and incompatible element ratios. Geochemistry, Geophysics, Geosystems 6, Q02L07, doi:10.129/2004GC000757.

Fuhrmann, U., Lippolt, H., Hess, J.C., 1987. HD-B1 Biotite reference material for K-Ar chronometry. Chemical Geology 66, 41-51.

Furman, T., Bryce, J., Rooney, T., Hana, B., Yirgu, G., Ayalew, D., 2006. Heads and tails: 30 million years of the Afar plume. In: Yirgu, G., Ebinger, C.J., Maguire, P.K.H., (Eds.), The Afar volcanic province within the East African Rift System. Geological Society of London, Special Publication 259, 95-119.

Gasse, F., Fournier, M., Richard, O., Ruegg, J.C., 1983. Carte géologique de la République de Djibouti à 1:100 000. Djibouti. Notice explicative. ISERST, Ministère français de la Coopération, Ed. ORSTOM, Paris, 70 pp.

Guillou, H., Singer, B., Laj, C., Kissel, C., Scaillet, S., Jicha, B.R., 2004. On the age of the Laschamp geomagnetic event. Earth and Planetary Science Letters, 227, 331-343.

Hart, S.R., 1984. A large-scale isotope anomaly in the Southern Hemisphere mantle. Nature 309, 753-757.

Hart, S.R., 1988. Heterogeneous mantle domains: signatures, genesis and mixing chronologies. Earth and Planetary Science Letters 90, 273-296.

Hart, S.R., Hauri, E.H., Oschmann, L.A., Whitehead, J.A., 1992. Mantle plumes and entrainment: isotopic evidence. Science 256, 517-520. 
Hart, W.K., Woldegabriel, G., Walter, R.C., Mertzman, S.A., 1989. Basaltic volcanism in Ethiopia: constraints on continental rifting and mantle interactions. Journal of Geophysical Research 94, 7731-7748.

Hase, K.M., Mühe, R., Stoffers, P., 2000. Magmatism during extension of the lithosphere: geochemical constraints from lavas of the Shaban Deep, northern Red Sea. Chemical Geology 166, 225-239.

Hémond, C., Arndt, N.T., Lichtenstein, U., Hofmann, A., 1993. The heterogeneous Iceland plume: Nd-Sr-O isotopes and trace element constraints. Journal of Geophysical Research 98, 15803-15850.

Hoernle, K., Werner, R., Phipps-Morgan, J., Garbe-Schönberg, D., Bryce, J., Mrazek, J., 2000. Existence of complex spatial zonation in the Galapagos plume for at least $14 \mathrm{~m}$. y. Geology 28, 435-438.

Ishizuka, O., Taylor, R.N., Milton, J.A., Nesbitt, R.W., 2003. Fluid-mantle interaction in an intraoceanic arc: constraints from high-precision $\mathrm{Pb}$ isotopes. Earth and Planetary Science Letters 211, 221-236.

Ito, E., White, W.M., Göpel, C., 1987. The O, Sr, Nd, and Pb isotope geochemistry of MORB. Chemical Geology 62, 157-176.

Joron, J.L., Treuil, M., Jaffrezic, H., Villemant, B., Richard, O., 1980. Géochimie des éléments en traces du volcanisme de l'Afar et de la mégastructure Mer Rouge-AfarGolfe d'Aden. Implications pétrogénétiques et géodynamiques. Bulletin de la Société géologique de France (7) 22, 945-957.

Johnson, C.M., Beard, B.L., 1999. Correction of instrumentally produced mass fractionation during isotopic analysis of Fe by thermal ionization mass spectrometry, International Journal of Mass Spectrometry 193, 87-99.

Kerr, A.C., Saunders, A.D., Tarney, J., Berry, N.H., Hards, V.L., 1995. Depleted mantleplume geochemical signatures: No paradox for plume theories. Geology 23, 843-846. 
Kokfelt, T.F., Hoernle, K., Hauf, F., Fiebig, J., Werner, R., Garbe-Schomberg, D., 2006. Combined trace element and $\mathrm{Pb}-\mathrm{Nd}-\mathrm{Sr}-\mathrm{O}$ isotope evidence for recycled oceanic crust(upper and lower) in the Iceland mantle plume. Journal of Petrology 47, 17051749.

679

Laughlin, A.W., Poths, S., Healey, H., Reneau, S., Woldegabriel, G., 1994. Dating Quaternary basalts using the $3 \mathrm{He}$ and $14 \mathrm{C}$ methods with implications for excess Ar.

Lin, S.-S., Keken, P.E. van, 2006. Dynamics of thermochemical plumes: 2. Complexity of 685 plume structures and its implications for mapping mantle plumes. Geochemistry, Geophysics, Geosystems 7, Q033003, doi:10.129/2005GC001072.

Manighetti, I., Tapponnier, P., Courtillot, V., Gruszow, S., Gillot., P.Y., 1997. Propagation 691

Meshesha, D., Shinjo, R., 2007. Crustal contamination and diversity of magma sources in 693 the Northwestern Ethiopian volcanic province. Journal of Mineralogical and Petrological Sciences, 102, 272-290.

Needham, H.D., Choukroune, P., Cheminée, J.-L., Le Pichon, X., Francheteau, J., 699

Odin, G.S., and 35 collaborators, 1982. Interlaboratory standards for dating purposes. In: 702 northwestern Ethiopian Plateau flood basalts: Classification and spatial distribution of magma types. Journal of Volcanology and Geothermal Research 81, 91-111. 
Pik, R., Deniel, C., Coulon, C., Yirgu, G., Marty, B., 1999. Isotopic and trace element signatures of Ethiopian flood basalts: evidence for plume-lithosphere interactions. Geochimica et Cosmochimica Acta 63, 2263-2279.

Rogers, N.W., 2006. Basaltic magmatism and the geodynamics of the East African Rift province within the East African Rift System. Geological Society of London, Special Publication 259, 77-93.

Scaillet, S., Guillou, H., 2004. A critical evaluation of young (near-zero) K-Ar ages. Earth and Planetary Science Letters 220, 265-275.

Schilling, J.G., 1973. Afar mantle plume: rare earth evidence. Nature 242, 2-5.

Schilling, J.G., Kingsley, R.H., Hanan, B.B., McCully, B.L., 1992. Nd-Sr-Pb variations along the Gulf of Aden: evidence for Afar Mantle plume-continental lithosphere interaction. Journal of Geophysical Research 97, 10927-10966.

Steiger, R.H., Jäger, E., 1977. Subcommission on geochronology: convention on the use of decay constants in geo- and cosmochronology. Earth and Planetary Science Letters 36,

Skovgaard, A.C., Storey, M., Baker, J., Blusztajn, J., Hart, S.R., 2001. Osmium-oxygen isotopic evidence for a recycled and strongly depleted component in the Iceland mantle plume. Earth and Planetary Science Letters 194, 259-275. 359-362. 
Stieltjes, L., Joron, J.L., Treuil, M., Varet, J., 1976. Le rift d'Asal, segment de dorsale émergée: discussion pétrologique et géochimique. Bulletin de la Société géologique de France (7) 18, 851-862.

Sun, S.S., McDonough, W.F., 1989. Chemical and isotopic systematics of oceanic basalts: Implications for mantle composition and processes. In: Saunders, A.D., Norry, M.J., (Eds.), Magmatism in the ocean basins. Geological Society of London Special Publication 42, 313-345.

Taylor, R.N., Thirlwall, M.F., Murton, B.J., Hilton, D.R., Gee, M.A.M., 1997. Isotopic constraints on the influence of the Icelandic plume. Earth and Planetary Science Letters $148,1-8$.

Thirlwall, M.F., 1995. Generation of the Pb isotopic characteristics of the Iceland plume. Journal of the Geological Society of London, 152, 991-996.

Thirlwall, M.F., Gee, M.A.M., Taylor, R.N., Murton, B.J., 2004. Mantle components in Iceland and adjacent ridges investigated using double-spike $\mathrm{Pb}$ isotope ratios. Geochimica et Cosmochimica Acta 68, 361-386.

Treuil, M., Joron, J.L., 1975. Utilisation des éléments hygromagmatophiles pour la simplification de la modélisation quantitative des processus magmatiques. Exemples de l'Afar et de la dorsale médioatlantique. Rendiconti della Società Italiana di Mineralogia e Petrologia 31, 125-174.

Vidal, P., Deniel, C., Vellutini, P.J., Piguet, P., Coulon, C., Vincent, J., Audin, J., 1991. Changes of mantle sources in the course of a rift evolution: the Afar case. Geophysical Research Letters 18, 1913-1916.

Volker, F., Altherr, R., Jochum, K.P., McCulloch, M.T., 1997. Quaternary volcanic activity of the southern Red Sea: new data and assessment of models on magma sources and Afar plume-lithosphere interaction. Tectonophysics 278, 15-29. 
Volker, F., McCulloch, M.T., Altherr, R.,1993. Submarine basalts from the Red Sea: new $\mathrm{Pb}, \mathrm{Sr}$, and Nd isotopic data. Geophysical Research Letters 20, 927-930.

White, W.M., McBirney, A.R., Duncan, R.A., 1993. Petrology and geochemistry of the Galapagos islands: portrait of a pathological mantle plume. Journal of Geophysical Research 98, 19533-19563.

Yang, H.-J., Frey, F.A., Clague, D.A., 2003. Constraints on the source components of lavas 783 forming the Hawaiian North Arch and Honolulu volcanoes. Journal of Petrology 44, 785 603-627.

Zindler, A., Hart, S.R., Frey, F.A., Jakobsson, S.P., 1979. Nd and $\mathrm{Sr}$ isotope ratios and rare 791 earth abundances in Reykjanes Peninsula basalts: evidence for mantle heterogeneity

\section{Figure captions}

799

800

801

802

Fig. 1. Geological setting of the Djibouti Plain. (a) Location of the study area in the Tadjoura 803

Fig. 2. Chondrite-normalized REE patterns of Hayyableh basalts compared to the field of older Tadjoura Gulf basalts located onland in Djibouti (Barrat et al., 1993; Daoud, 2008). The reference chondrite is from Evensen et al. (1978). The pattern of a southern Red Sea NMORB (sample V84, Barrat etal., 1990) is shown for comparison. 
809 Fig. 3. Primitive mantle-normalized element patterns for Hayyabley basalts, LREE-depleted

810 Manda Hararo basalts (Barrat et al., 2003), two submarine MORB from the East of the Gulf 811 of Tadjoura (Barrat et al., 1990, 1993), the southern Red Sea N-MORB sample V84 (Barrat 812 et al., 1990), and the LREE-depleted sample E88 from the Oligocene Ethiopian Plateau (Pik 813 et al., 1999). The primitive mantle values are from Sun and McDonough (1989).

815 Fig. 4. Plot of $\varepsilon_{\mathrm{Nd}}$ Vs. ${ }^{87} \mathrm{Sr} /{ }^{86} \mathrm{Sr}$ for young onland basalts from Djibouti (Deniel et al., 1994, and 816 this study). Only the two reliable Sr isotopic ratios of Hayyabley basalts have been plotted. 817 Basalts older than $4 \mathrm{Ma}$ have been omitted because of their possible contamination by 818 continental crust. The fields of (1) basalts from the South Red Sea occurrences, which include 819 oceanic ridge segments, Ramad seamount and Zubair and Hanish islands (Barrat et al., 1990, 820 1993; Volker et al., 1993, 1997), (2) submarine basalts from the East of the Gulf of Tadjoura 821 and the Aden Gulf (Barrat et al., 1990, 1993; Schilling et al., 1992), (3) Erta 'Ale volcanics 822 (Barrat et al., 1998), (4) LREE-depleted basalts from Manda Hararo (MH, Barrat et al., 2003), 823 and (5) some Ethiopian samples (E88: depleted Oligocene basalt; HT2: average composition 824 of high-Ti basalts, Pik et al., 1999) are shown for comparison. DM refers to the regional 825 depleted mantle composition deduced from the study of South Red Sea and Gulf of Aden 826 basalts.

828 Fig. 5. Plot of ${ }^{207} \mathrm{~Pb} /{ }^{204} \mathrm{~Pb}$ and ${ }^{208} \mathrm{~Pb} /{ }^{204} \mathrm{~Pb}$ vs. ${ }^{206} \mathrm{~Pb} /{ }^{204} \mathrm{~Pb}$ for young (less than $4 \mathrm{Ma}$ ) onland 829 enriched basalts from Djibouti (Deniel et al., 1994) and Hayyabley depleted basalts (this 830 study). Other fields as in Fig. 4. E'A: field of Erta 'Ale volcanics (Barrat et al., 1998). Most $831{ }^{207} \mathrm{~Pb} /{ }^{204} \mathrm{~Pb}$ data taken from the regional literature (e.g. on E88 and Erta 'Ale) are less precise 832 than those measured on Hayyabley basalts, and should therefore be considered with caution.

834 Fig. 6. Plot of ${ }^{206} \mathrm{~Pb} /{ }^{204} \mathrm{~Pb}$ vs. $\varepsilon_{\mathrm{Nd}}$ for young (less than $4 \mathrm{Ma}$ ) onland enriched basalts from 835 Djibouti (Deniel et al., 1994) and Hayyabley depleted basalts (this study). Other fields as in 836 Fig. 5.

\section{Table captions}

840 Table 1. Unspiked ${ }^{40} \mathrm{~K}-{ }^{40} \mathrm{Ar}$ datings of Hayyabley basalts. See text for the analytical 841 procedures. 
843 Table 2. Major and trace element analyses of Hayyabley basalts (major oxides in wt\%, trace

844 elements in ppm). ICP-AES and ICP-MS analytical methods described in the text.

845

846 Table 3. Compositions of LREE-depleted basalts from Hayyabley (average of the samples 847 analysed by ICP-MS), Manda Hararo (average data from Barrat et al., 2003), Ethiopian 848 Plateau (sample E88, Pik et al., 1999), and of a N-MORB from Tadjoura Gulf (sample A3D3, 849 Joron et al., 1980; Barrat et al., 1993). Major oxides in wt\%, trace elements in ppm. n denotes 850 ratios normalized to the primitive mantle composition from Sun and McDonough (1989).

851

852 Table 4. Sr, $\mathrm{Nd}$ and $\mathrm{Pb}$ isotopic compositions of Hayyabley basalts (B: bulk rock; R: residue 853 after leaching). See text for the analytical procedures. $\Delta 7 / 4$ and $\Delta 8 / 4$ denote the deviation (in $854{ }^{0} \%$ ) of ${ }^{207} \mathrm{~Pb} /{ }^{204} \mathrm{~Pb}$ and ${ }^{208} \mathrm{~Pb} /{ }^{204} \mathrm{~Pb}$ ratios with respect to the Northern Hemisphere Reference 855 Line (NHRL: Hart, 1984, 1988). 


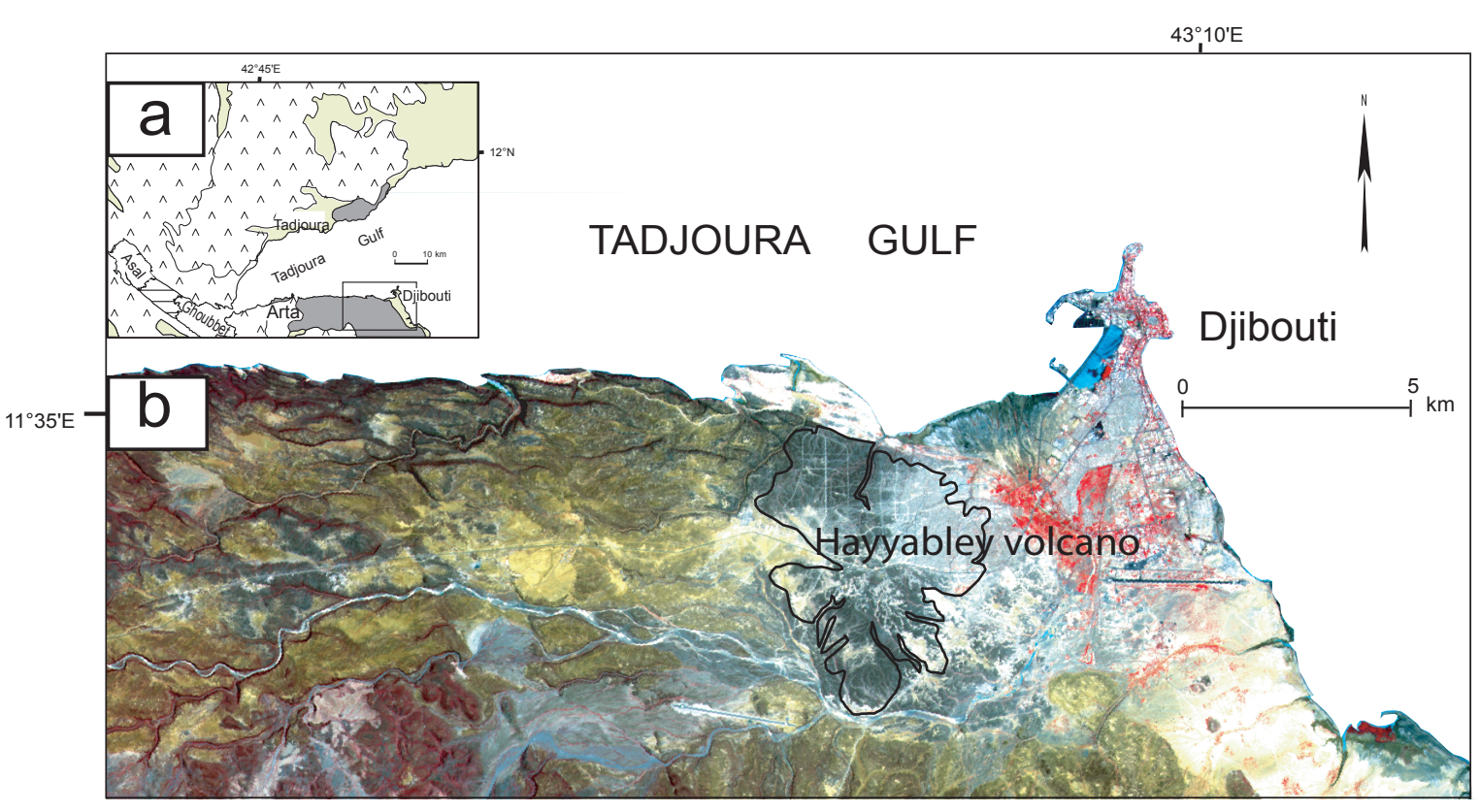

$43^{\circ} 10^{\circ} \mathrm{E}$

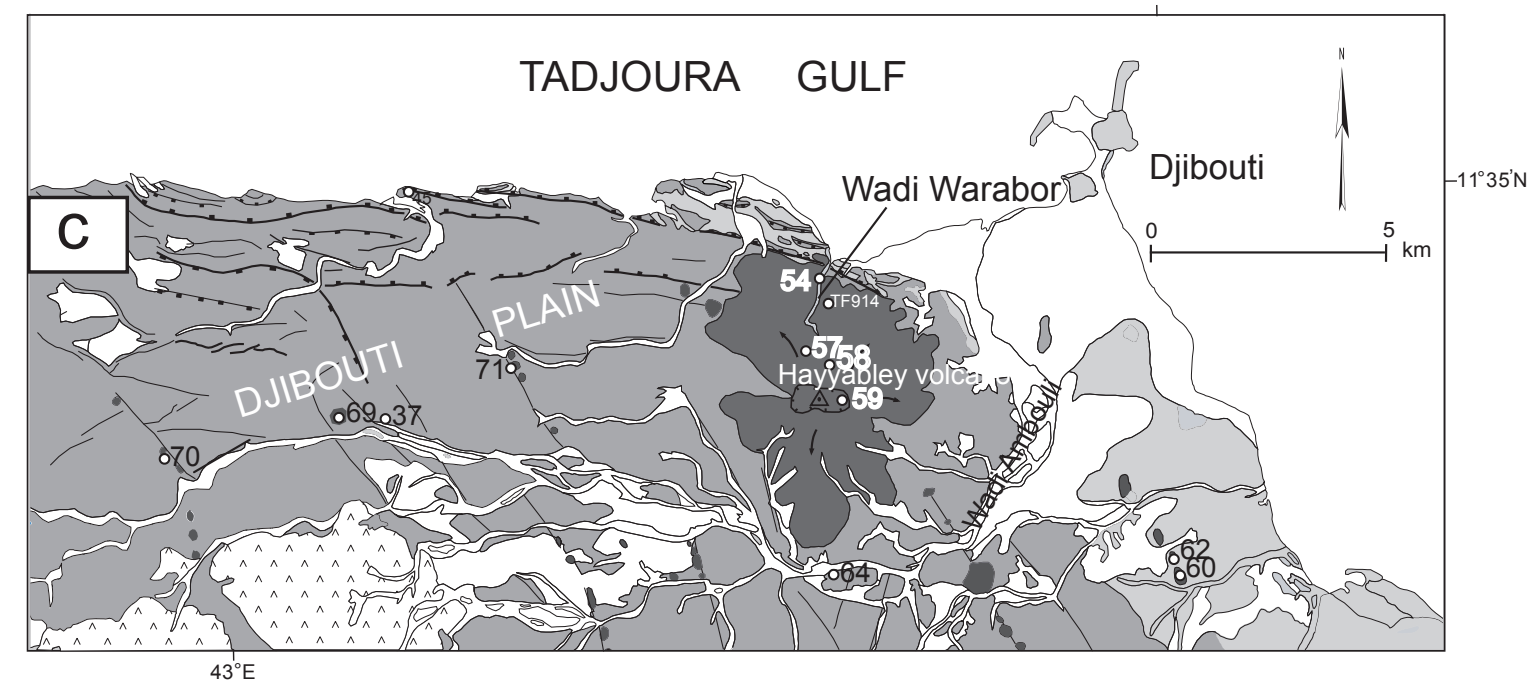

Recent deposits

Upper Pleistocene fluvial deposits and reef limestone Asal basalts

Quaternary volcanoes

Tadjoura Gulf Basalts

Mabla rhyolites-Dalha and Somali basalts
- Main normal faults

Secondary normal faults

$\Delta$ Signal Bouêt $127 \mathrm{~m}$

as Summit zone

- Flow direction

${ }_{540}$ Sampling location

Figure 1: Geology and tectonics of Djibouti Plain 


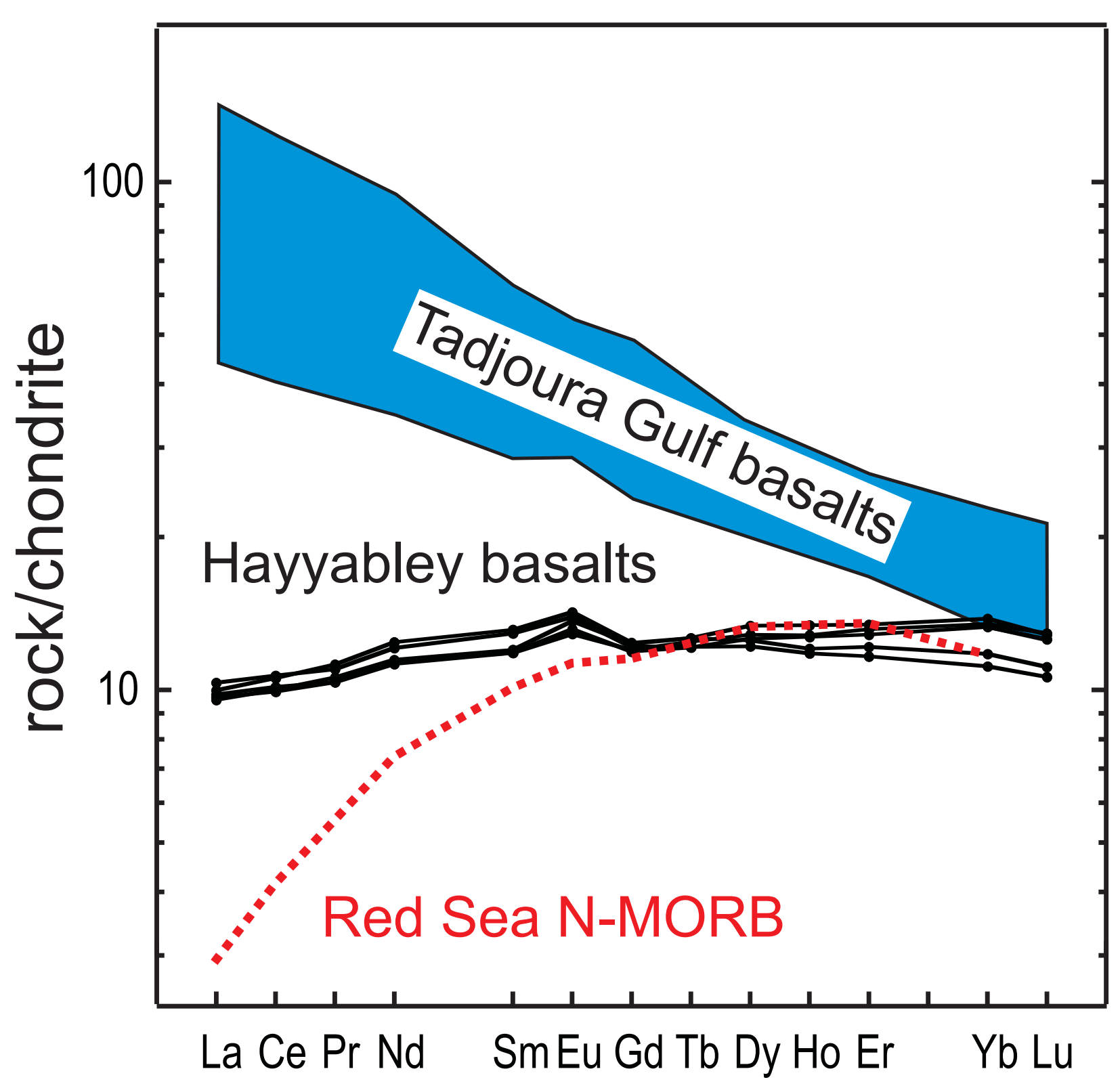

Figure 2 


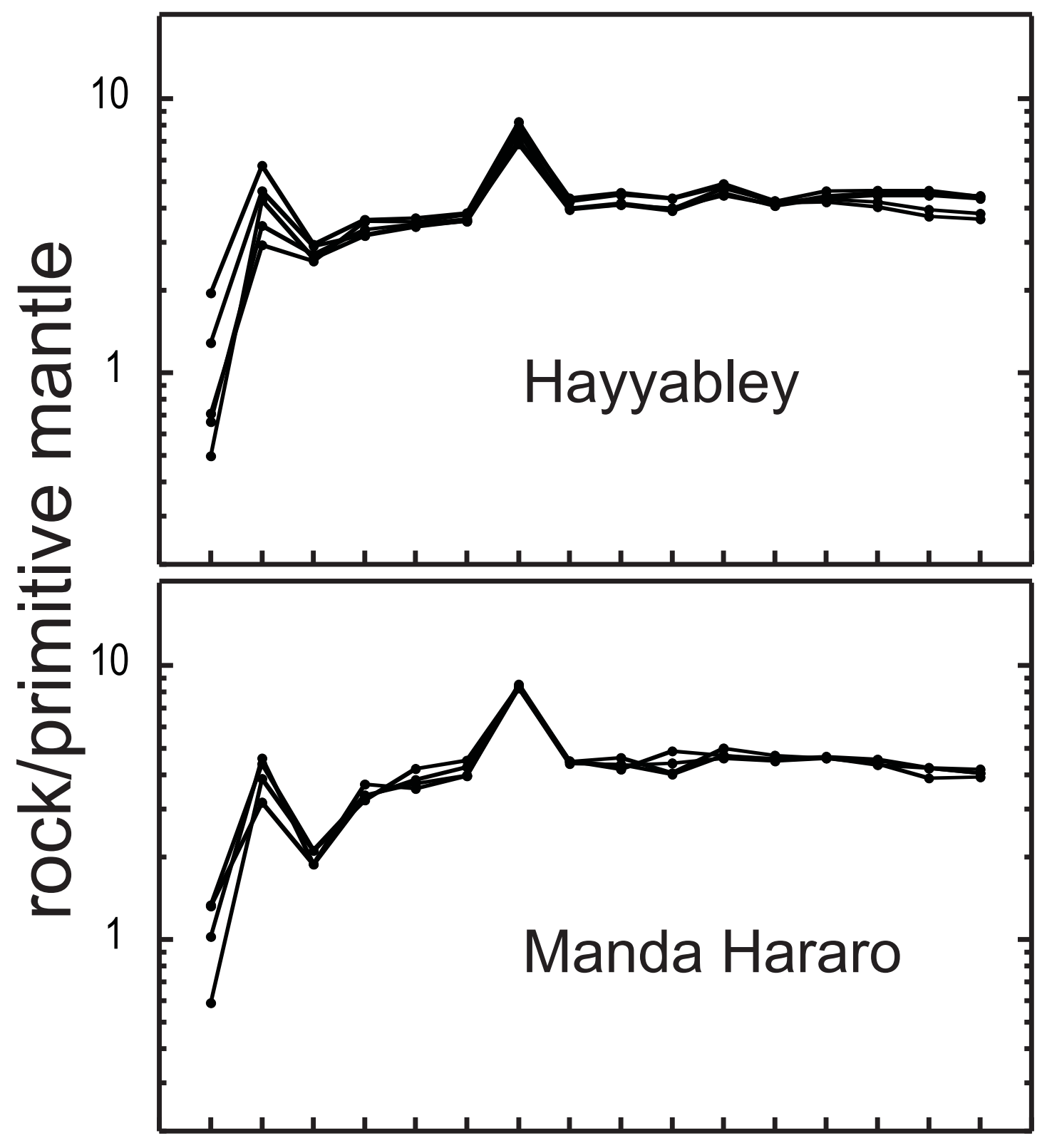

$\mathrm{Rb} \mathrm{Ba}$ Th Nb La Ce Sr NdSmHf Eu GdDy Er Yb Lu

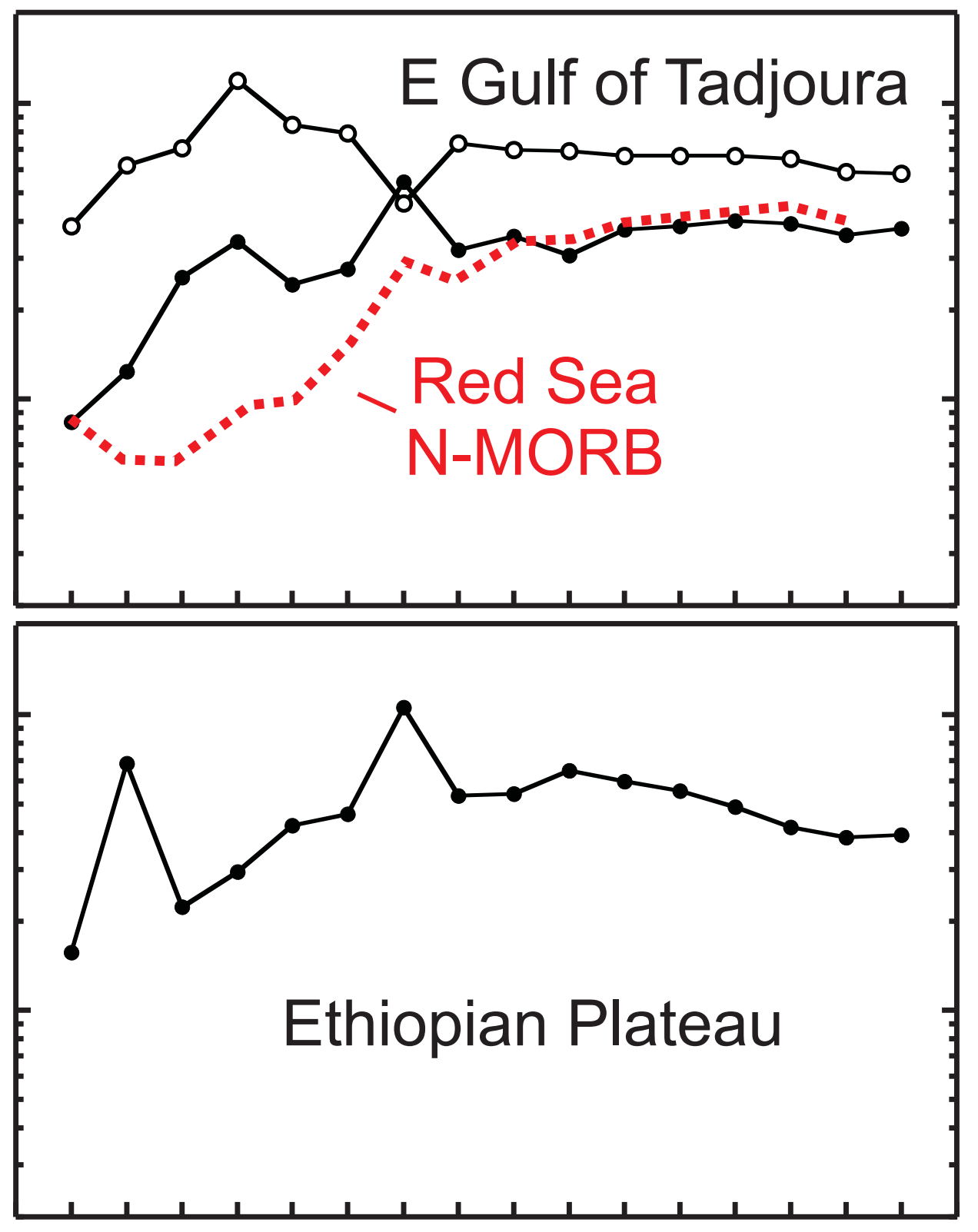

$\mathrm{Rb}$ Ba Th Nb La Ce Sr NdSmHf Eu GdDy Er Yb Lu 


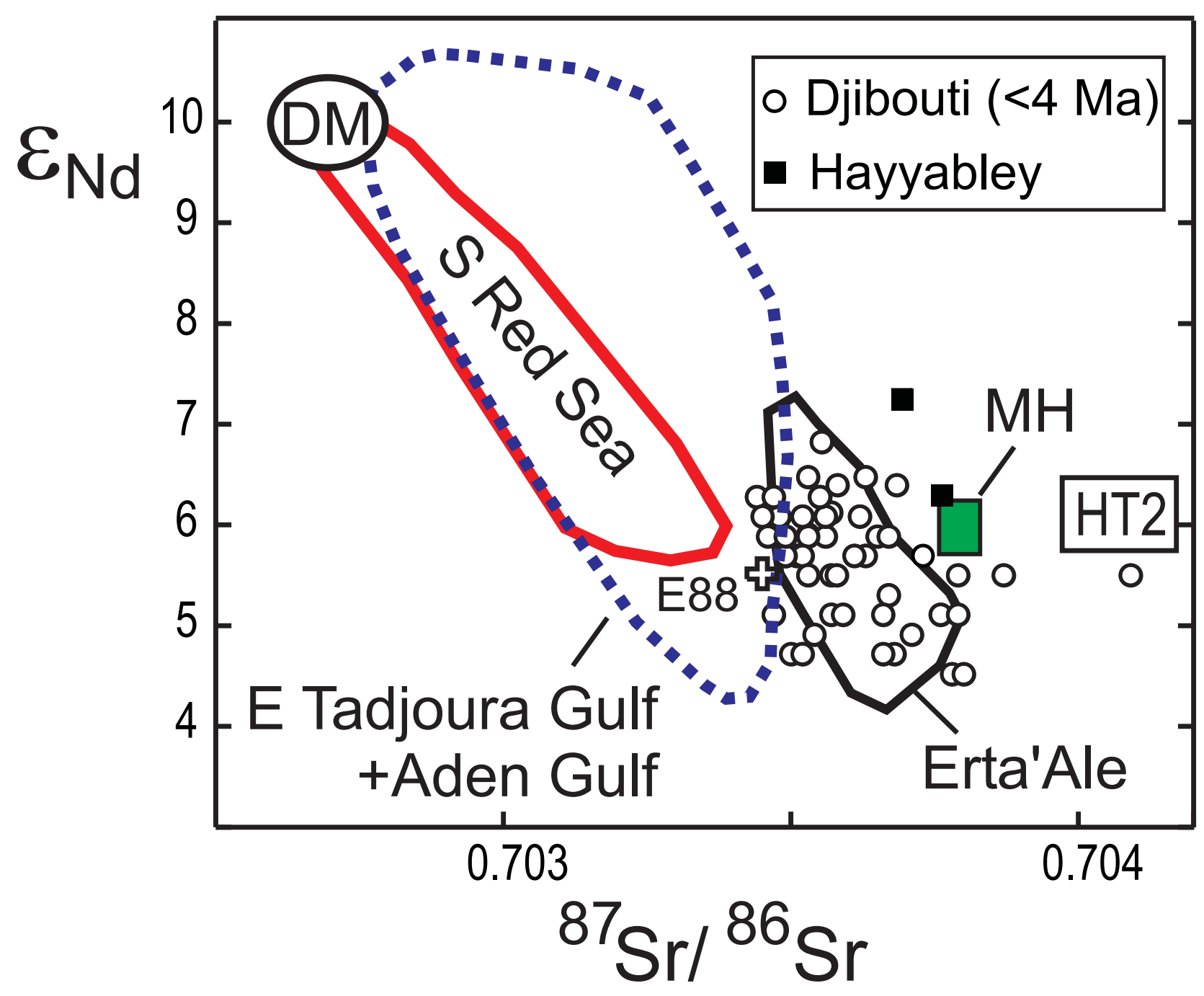



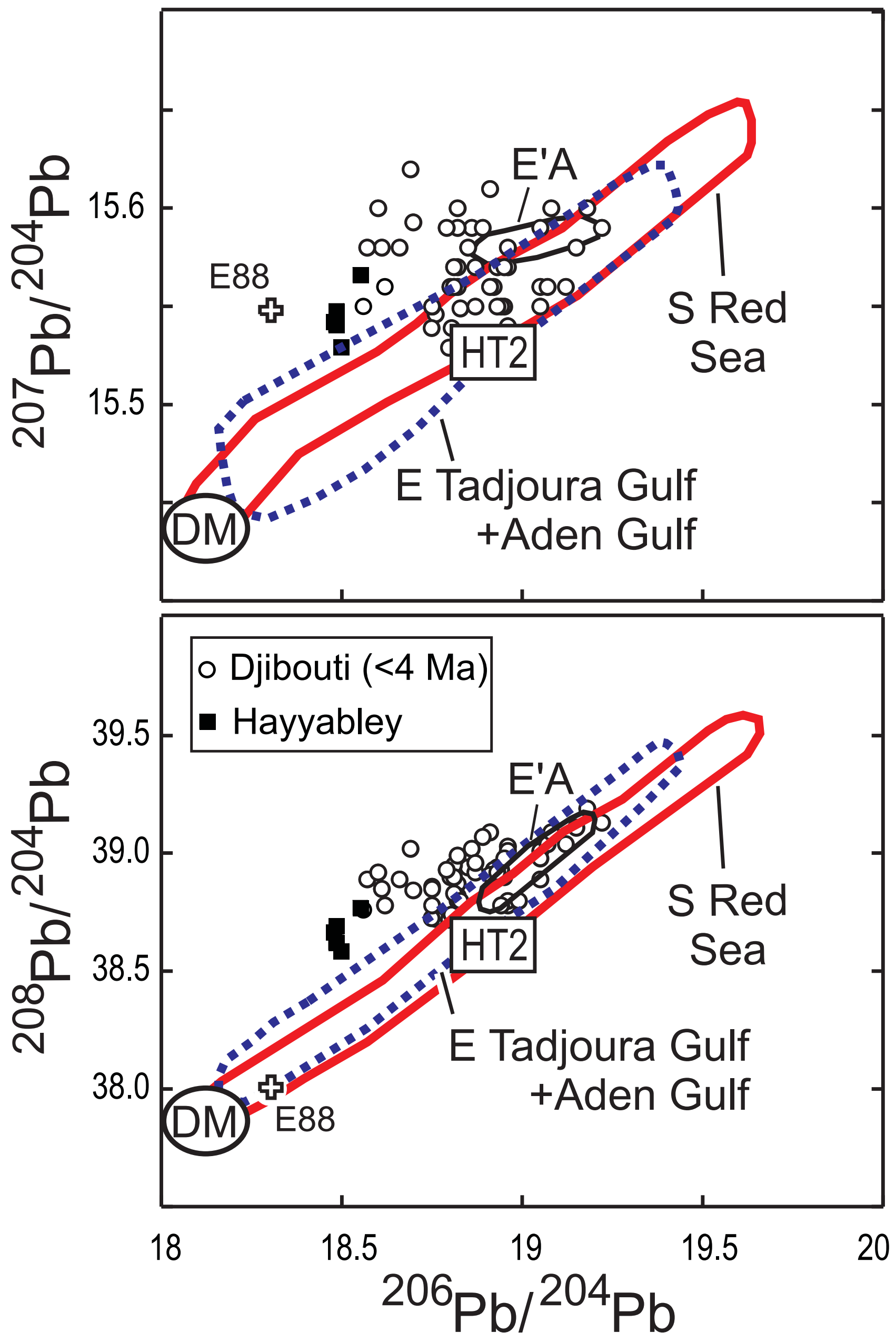


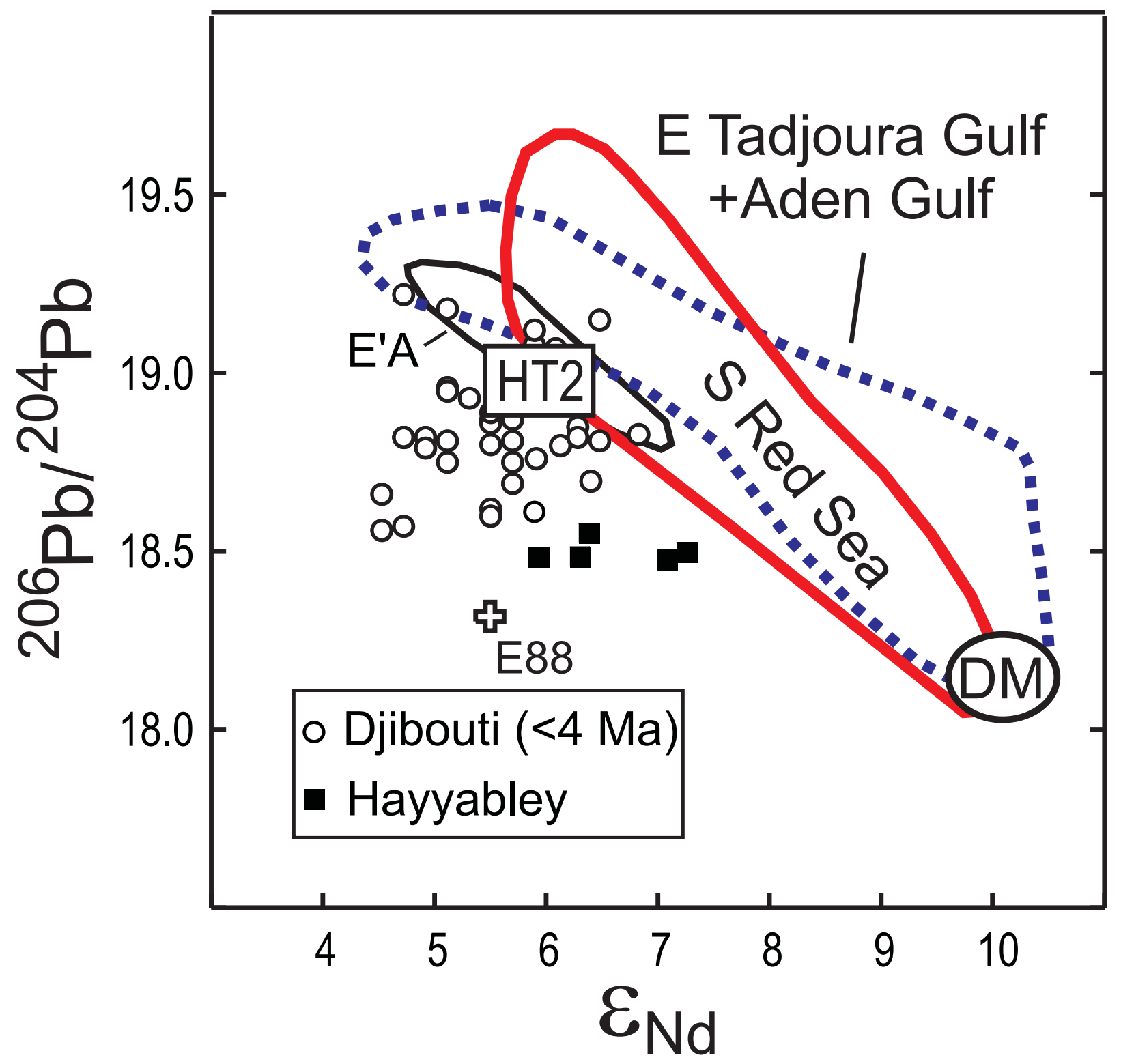


1 Table 1. Unspiked ${ }^{40} \mathrm{~K}-{ }^{40} \mathrm{Ar}$ datings of Hayyabley basalts. See text for the analytical 2 procedures.

3

\begin{tabular}{|c|c|c|c|c|c|c|}
\hline $\begin{array}{l}\text { Sample id } \\
\text { Experiment } \\
\#\end{array}$ & $\begin{array}{l}\text { Split } \\
\qquad \begin{array}{l}\text { K (wt } \%) \\
\quad \pm 1 \sigma\end{array}\end{array}$ & $\begin{array}{l}\text { Mass } \\
\text { molten } \\
(\mathrm{g})\end{array}$ & ${ }^{40} \mathrm{Ar} \%$ & $\begin{array}{c}40 \mathrm{Ar}^{*} 10^{-13} \\
(\mathrm{~mol} . / \mathrm{g}) \\
\pm 1 \sigma\end{array}$ & $\begin{array}{l}\text { Weighted mean } \\
\begin{array}{c}40 A r^{*} 10^{-13} \\
(\mathrm{~mol} . / \mathrm{g}) \\
\pm 1 \sigma\end{array}\end{array}$ & $\begin{array}{l}\text { Age } \\
(\mathrm{Ma}) \\
\pm 2 \sigma \\
\end{array}$ \\
\hline \multicolumn{7}{|l|}{ DJ54B } \\
\hline 7040 & $0.09 \pm 0.005$ & 2.10972 & 1.254 & $1.430 \pm 0.057$ & & \\
\hline $\begin{array}{l}7056 \\
\text { DJ54F }\end{array}$ & « ............. & 2.07428 & 1.213 & $1.468 \pm 0.058$ & $1.449 \pm 0.041$ & $0.93 \pm 0.06$ \\
\hline 7039 & $0.04 \pm 0.004$ & 2.77642 & 0.577 & $0.642 \pm 0.046$ & & \\
\hline 7063 & « $\ldots \ldots \ldots \ldots \ldots \|$ & 3.01844 & 0.699 & $0.745 \pm 0.040$ & $0.701 \pm 0.030$ & $1.06 \pm 0.09$ \\
\hline
\end{tabular}

4

5 Table 1. 
1 Table 2. Major and trace element analyses of Hayyabley basalts (major oxides in wt\%, trace elements in ppm). ICP-AES and ICP-MS analytical 2 methods described in the text.

3

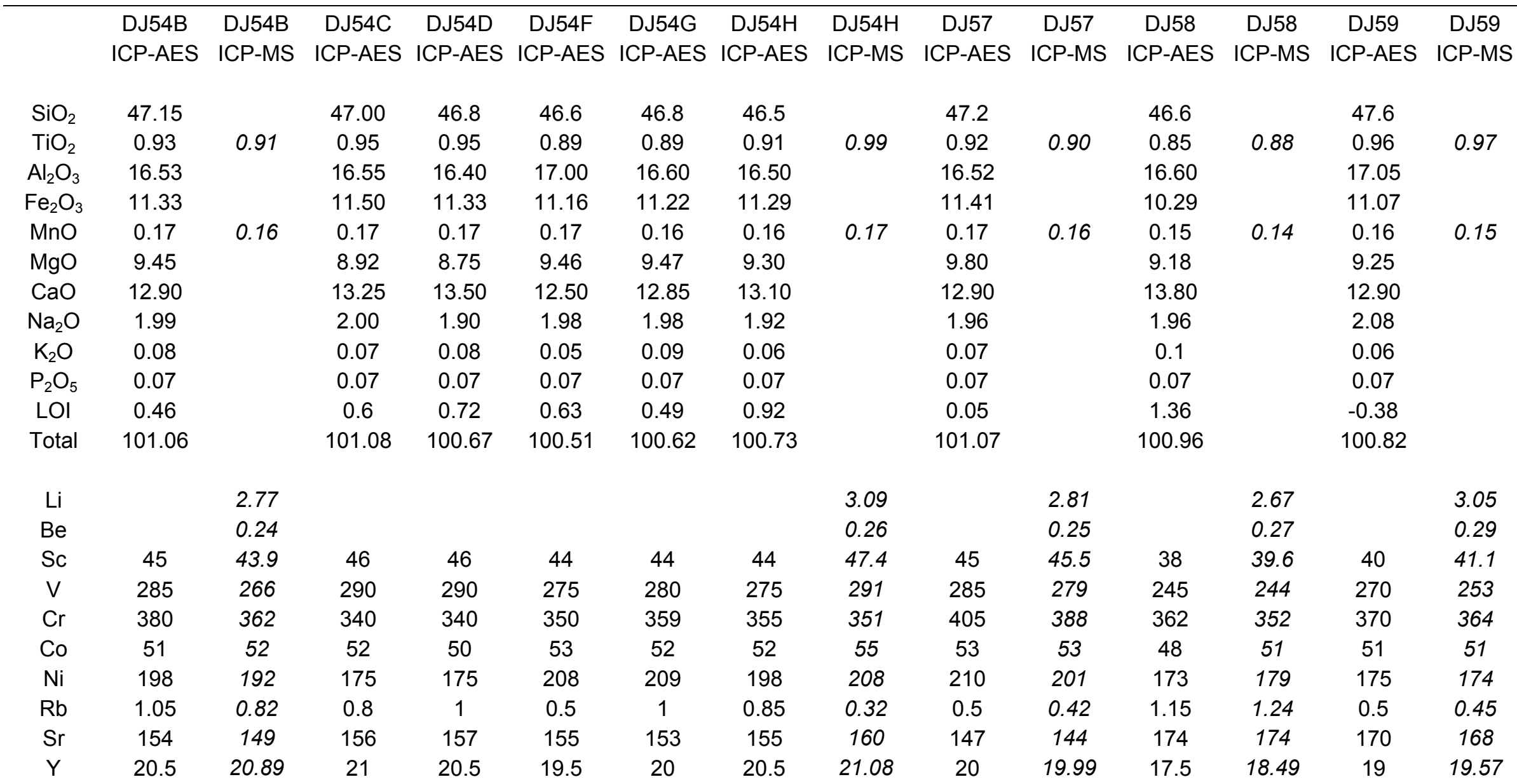




$\begin{array}{ccccccccccccccc}\mathrm{Zr} & 48 & 44.91 & 48 & 47 & 43 & 46 & 47 & 44.09 & 44 & 42.81 & 45 & 46.87 & 48 & 47.77 \\ \mathrm{Nb} & 2.7 & 2.28 & 2.5 & 2.4 & 2.5 & 2.45 & 2.3 & 2.26 & 2.4 & 2.37 & 2.6 & 2.59 & 2.4 & 2.56\end{array}$

$4 \quad$ Table 2 (continued).

5

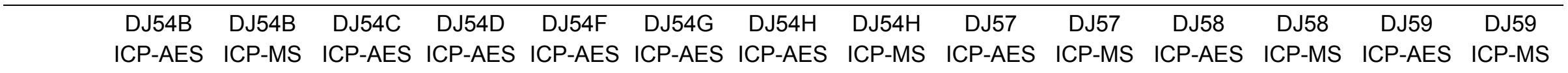

\begin{tabular}{|c|c|c|c|c|c|c|c|c|c|c|c|c|c|c|}
\hline $\mathrm{Ba}$ & 34 & 32.19 & 41 & 55 & 40 & 50 & 30 & 29.81 & 25 & 24.11 & 40 & 40.01 & 22 & 20.49 \\
\hline La & 2.6 & 2.37 & 2.5 & 2.4 & 2.5 & 2.4 & 2.5 & 2.34 & 2.7 & 2.40 & 2.7 & 2.53 & 2.5 & 2.44 \\
\hline $\mathrm{Ce}$ & 7.1 & 6.34 & 7.0 & 6.5 & 6.3 & 6.4 & 6.7 & 6.38 & 6.5 & 6.47 & 7.3 & 6.81 & 7.0 & 6.73 \\
\hline $\operatorname{Pr}$ & & 1.00 & & & & & & 1.02 & & 1.00 & & 1.06 & & 1.08 \\
\hline $\mathrm{Nd}$ & 5.3 & 5.39 & 5.5 & 5.3 & 4.8 & 5.2 & 5.4 & 5.43 & 5.4 & 5.34 & 5.4 & 5.73 & 5.8 & 5.89 \\
\hline Sm & 2.0 & 1.82 & 2.0 & 1.7 & 1.9 & 1.7 & 1.8 & 1.85 & 1.9 & 1.82 & 1.8 & 1.99 & 1.9 & 2.02 \\
\hline $\mathrm{Eu}$ & 0.8 & 0.75 & 0.78 & 0.78 & 0.73 & 0.76 & 0.77 & 0.79 & 0.74 & 0.76 & 0.75 & 0.81 & 0.82 & 0.83 \\
\hline $\mathrm{Gd}$ & 2.3 & 2.45 & 2.3 & 2.4 & 2.5 & 2.05 & 2.4 & 2.52 & 2.3 & 2.43 & 2.5 & 2.48 & 2.5 & 2.53 \\
\hline $\mathrm{Tb}$ & & 0.47 & & & & & & 0.47 & & 0.45 & & 0.46 & & 0.47 \\
\hline Dy & 3.3 & 3.26 & 3.4 & 3.3 & 3.1 & 3.15 & 3.25 & 3.40 & 3.25 & 3.21 & 2.9 & 3.10 & 3.25 & 3.18 \\
\hline Ho & & 0.73 & & & & & & 0.76 & & 0.72 & & 0.67 & & 0.68 \\
\hline $\mathrm{Er}$ & 2.1 & 2.19 & 2.1 & 2.1 & 2 & 2.1 & 2.15 & 2.23 & 2 & 2.14 & 1.8 & 1.93 & 1.9 & 2.02 \\
\hline $\mathrm{Yb}$ & 2.18 & 2.23 & 2.29 & 2.2 & 2.08 & 2.1 & 2.15 & 2.28 & 2.1 & 2.20 & 1.75 & 1.84 & 1.9 & 1.95 \\
\hline Lu & & 0.33 & & & & & & 0.33 & & 0.32 & & 0.27 & & 0.28 \\
\hline $\mathrm{Hf}$ & & 1.23 & & & & & & 1.23 & & 1.21 & & 1.34 & & 1.34 \\
\hline $\mathrm{Ta}$ & & 0.17 & & & & & & 0.18 & & 0.18 & & 0.19 & & 0.19 \\
\hline $\mathrm{Pb}$ & & 0.26 & & & & & & 0.23 & & 0.26 & & 0.24 & & 0.26 \\
\hline Th & & 0.25 & & & & & & 0.22 & & 0.23 & & 0.25 & & 0.22 \\
\hline$U$ & & 0.06 & & & & & & 0.06 & & 0.05 & & 0.07 & & 0.03 \\
\hline
\end{tabular}


Table 3. Compositions of light REE depleted basalts from Hayyabley (average of the samples analyzed by ICP-MS), Manda Hararo (average from data given by Barrat et al., 2003), Ethiopian Plateau (sample E88, Pik et al., 1999), and of a N-MORB from Tadjoura Gulf (sample A3D3, Joron et al., 1980; Barrat et al., 1993). (oxides in wt\%, traces elements in $\mu \mathrm{g} / \mathrm{g})$.

\begin{tabular}{|c|c|c|c|c|}
\hline & $\begin{array}{c}\text { Hayyabley } \\
(\mathrm{n}=5)\end{array}$ & $\begin{array}{c}\text { Manda } \\
\text { Hararo } \\
(\mathrm{n}=4)\end{array}$ & $\begin{array}{c}\text { Ethiopian } \\
\text { Plateau } \\
(n=1)\end{array}$ & $\begin{array}{c}\text { Tadjoura } \\
\text { Gulf } \\
(\mathrm{n}=1)\end{array}$ \\
\hline $\mathrm{SiO}_{2}$ & 47.01 & 48.50 & 48.05 & 48.40 \\
\hline $\mathrm{TiO}_{2}$ & 0.91 & 1.04 & 1.08 & 0.83 \\
\hline $\mathrm{Al}_{2} \mathrm{O}_{3}$ & 16.64 & 15.50 & 16.05 & 15.50 \\
\hline $\mathrm{Fe}_{2} \mathrm{O}_{3}$ & 11.08 & 11.94 & 11.63 & 9.78 \\
\hline $\mathrm{MnO}$ & 0.16 & 0.18 & 0.17 & 0.13 \\
\hline $\mathrm{MgO}$ & 9.40 & 8.47 & 8.67 & 8.83 \\
\hline $\mathrm{CaO}$ & 13.12 & 11.32 & 10.58 & 12.90 \\
\hline $\mathrm{Na}_{2} \mathrm{O}$ & 1.98 & 2.33 & 2.38 & 2.06 \\
\hline $\mathrm{K}_{2} \mathrm{O}$ & 0.07 & 0.08 & 0.16 & 0.09 \\
\hline $\mathrm{P}_{2} \mathrm{O}_{5}$ & 0.07 & 0.08 & 0.10 & 0.05 \\
\hline total & 100.93 & 99.44 & 98.87 & 98.57 \\
\hline $\mathrm{Sc}$ & 43.5 & 36.7 & & 37.9 \\
\hline V & 267 & 260 & 229 & \\
\hline $\mathrm{Cr}$ & 363 & 64 & 182 & \\
\hline Co & 52.4 & 54.80 & & 47.7 \\
\hline $\mathrm{Ni}$ & 191 & 101 & 152 & 139 \\
\hline $\mathrm{Rb}$ & 0.65 & 0.68 & 1.0 & 0.53 \\
\hline $\mathrm{Sr}$ & 159 & 177 & 224 & 114.5 \\
\hline $\mathrm{Y}$ & 20.0 & 23 & 21 & \\
\hline $\mathrm{Zr}$ & 45 & 41 & 61 & \\
\hline $\mathrm{Nb}$ & 2.41 & 2.43 & 2.1 & \\
\hline $\mathrm{Ba}$ & 29.32 & 28.01 & 48 & 8.68 \\
\hline $\mathrm{La}$ & 2.42 & 2.63 & 2.9 & 1.68 \\
\hline $\mathrm{Ce}$ & 6.55 & 7.41 & 8.2 & 4.90 \\
\hline $\mathrm{Nd}$ & 5.56 & 6.03 & 7.2 & 4.33 \\
\hline $\mathrm{Sm}$ & 1.90 & 1.94 & 2.40 & 1.58 \\
\hline $\mathrm{Eu}$ & 0.79 & 0.80 & 1.00 & 0.63 \\
\hline $\mathrm{Gd}$ & 2.48 & 2.73 & 3.30 & 2.30 \\
\hline Dy & 3.23 & 3.40 & 3.60 & 2.96 \\
\hline $\mathrm{Er}$ & 2.10 & 2.14 & 2.00 & 1.88 \\
\hline $\mathrm{Yb}$ & 2.10 & 2.04 & 1.90 & 1.77 \\
\hline $\mathrm{Lu}$ & 0.31 & 0.30 & 0.29 & 0.28 \\
\hline $\mathrm{Hf}$ & 1.27 & 1.34 & 2.0 & 0.95 \\
\hline $\mathrm{Ta}$ & 0.18 & 0.18 & 0.1 & 0.14 \\
\hline Th & 0.23 & 0.17 & 0.19 & 0.18 \\
\hline $\mathrm{U}$ & 0.05 & 0.06 & 0.06 & 0.28 \\
\hline$(\mathrm{La} / \mathrm{Sm}) \mathrm{n}$ & 0.80 & 0.85 & 0.76 & 0.67 \\
\hline $\mathrm{Eu} / \mathrm{Eu}^{*}$ & 1.11 & 1.06 & 1.09 & 1.01 \\
\hline$(\mathrm{Ba} / \mathrm{Rb}) \mathrm{n}$ & 4.10 & 3.75 & 4.36 & 1.49 \\
\hline$(\mathrm{Sr} / \mathrm{Ce}) \mathrm{n}$ & 2.04 & 2.01 & 2.30 & 1.97 \\
\hline
\end{tabular}


Table 4. $\mathrm{Sr}, \mathrm{Nd}$ and $\mathrm{Pb}$ isotopic compositions for Hayyabley basalts (R: residue after leaching).

\begin{tabular}{lccccc}
\hline & DJ54B & DJ54H & DJ57 & DJ58 & DJ59 \\
& & & & & \\
${ }^{87} \mathrm{Sr} /{ }^{86} \mathrm{Sr}$ & $0.703909 \pm 3$ & $0.703962 \pm 5$ & $0.703869 \pm 4$ & $0.703871 \pm 4$ & $0.703693 \pm 5$ \\
${ }^{87} \mathrm{Sr} /{ }^{86} \mathrm{Sr}(\mathrm{R})$ & $0.703762 \pm 9$ & & & & \\
& & & & & \\
${ }^{143} \mathrm{Nd} /{ }^{144} \mathrm{Nd}$ & $0.512961 \pm 4$ & $0.513001 \pm 3$ & $0.512965 \pm 4$ & $0.512942 \pm 3$ & $0.513010 \pm 4$ \\
$\varepsilon \mathrm{Nd}$ & +6.3 & +7.1 & +6.4 & +5.9 & +7.3 \\
& & & & & \\
${ }^{206} \mathrm{~Pb} /{ }^{204} \mathrm{~Pb}(\mathrm{R})$ & $18.4856 \pm 15$ & $18.4776 \pm 15$ & $18.5502 \pm 27$ & $18.4842 \pm 17$ & $18.4979 \pm 21$ \\
${ }^{207} \mathrm{~Pb} /{ }^{204} \mathrm{~Pb}(\mathrm{R})$ & $15.5478 \pm 14$ & $15.5421 \pm 14$ & $15.5662 \pm 25$ & $15.5407 \pm 16$ & $15.5292 \pm 20$ \\
${ }^{208} \mathrm{~Pb} /{ }^{204} \mathrm{~Pb}(\mathrm{R})$ & $38.6917 \pm 43$ & $38.6658 \pm 44$ & $38.7692 \pm 78$ & $38.6217 \pm 50$ & $38.5842 \pm 61$ \\
${ }^{\Delta 7 / 4}$ & 5.3 & 4.8 & 6.4 & 4.6 & 3.3 \\
${ }^{\Delta 8 / 4}$ & 71.6 & 69.9 & 71.5 & 64.7 & 59.3 \\
& & & & & \\
\hline
\end{tabular}




\begin{tabular}{|c|c|c|c|c|}
\hline & Hayyabley & $\begin{array}{l}\text { Manda } \\
\text { Hararo }\end{array}$ & $\begin{array}{c}\text { Ethiopian } \\
\text { Plateau }\end{array}$ & $\begin{array}{c}\text { Tadjoura } \\
\text { Gulf }\end{array}$ \\
\hline & $(n=5)$ & $(n=4)$ & $(n=1)$ & $(\mathrm{n}=1)$ \\
\hline $\mathrm{SiO} 2$ & 47.01 & 48.50 & 48.05 & 48.40 \\
\hline $\mathrm{TiO} 2$ & 0.91 & 1.04 & 1.08 & 0.83 \\
\hline $\mathrm{A} 12 \mathrm{O} 3$ & 16.64 & 15.50 & 16.05 & 15.50 \\
\hline $\mathrm{Fe} 2 \mathrm{O} 3$ & 11.08 & 11.94 & 11.63 & 9.78 \\
\hline $\mathrm{MnO}$ & 0.16 & 0.18 & 0.17 & 0.13 \\
\hline $\mathrm{MgO}$ & 9.40 & 8.47 & 8.67 & 8.83 \\
\hline $\mathrm{CaO}$ & 13.12 & 11.32 & 10.58 & 12.90 \\
\hline $\mathrm{Na} 2 \mathrm{O}$ & 1.98 & 2.33 & 2.38 & 2.06 \\
\hline $\mathrm{K} 2 \mathrm{O}$ & 0.07 & 0.08 & 0.16 & 0.09 \\
\hline $\mathrm{P} 2 \mathrm{O} 5$ & 0.07 & 0.08 & 0.10 & 0.05 \\
\hline total & 100.93 & 99.44 & 98.87 & 98.57 \\
\hline $\mathrm{Sc}$ & 43.5 & 36.7 & & 37.9 \\
\hline V & 267 & 260 & 229 & \\
\hline $\mathrm{Cr}$ & 363 & 64 & 182 & \\
\hline Co & 52.4 & 54.80 & & 47.7 \\
\hline $\mathrm{Ni}$ & 191 & 101 & 152 & 139 \\
\hline $\mathrm{Rb}$ & 0.65 & 0.68 & 1.0 & 0.53 \\
\hline $\mathrm{Sr}$ & 159 & 177 & 224 & 114.5 \\
\hline $\mathrm{Y}$ & 20.0 & 23 & 21 & \\
\hline $\mathrm{Zr}$ & 45 & 41 & 61 & \\
\hline $\mathrm{Nb}$ & 2.41 & 2.43 & 2.1 & \\
\hline $\mathrm{Ba}$ & 29.32 & 28.01 & 48 & 8.68 \\
\hline $\mathrm{La}$ & 2.42 & 2.63 & 2.9 & 1.68 \\
\hline $\mathrm{Ce}$ & 6.55 & 7.41 & 8.2 & 4.90 \\
\hline $\mathrm{Nd}$ & 5.56 & 6.03 & $\underline{7.2}$ & 4.33 \\
\hline $\mathrm{Sm}$ & 1.90 & 1.94 & $\overline{2.40}$ & 1.58 \\
\hline $\mathrm{Eu}$ & 0.79 & 0.80 & 1.00 & 0.63 \\
\hline Gd & 2.48 & 2.73 & 3.30 & 2.30 \\
\hline Dy & 3.23 & 3.40 & 3.60 & 2.96 \\
\hline $\mathrm{Er}$ & 2.10 & 2.14 & 2.00 & 1.88 \\
\hline $\mathrm{Yb}$ & 2.10 & 2.04 & 1.90 & 1.77 \\
\hline $\mathrm{Lu}$ & 0.31 & 0.30 & 0.29 & 0.28 \\
\hline $\mathrm{Hf}$ & 1.27 & 1.34 & 2.0 & 0.95 \\
\hline $\mathrm{Ta}$ & 0.18 & 0.18 & 0.1 & 0.14 \\
\hline Th & 0.23 & 0.17 & 0.19 & 0.18 \\
\hline $\mathrm{U}$ & 0.05 & 0.06 & 0.06 & 0.28 \\
\hline$(\mathrm{La} / \mathrm{Sm}) \mathrm{n}$ & 0.80 & 0.85 & 0.76 & 0.67 \\
\hline $\mathrm{Eu} / \mathrm{Eu}^{*}$ & 1.11 & 1.06 & 1.09 & 1.01 \\
\hline $\mathrm{Ba} / \mathrm{Rb}$ & 45.11 & 41.26 & 48.00 & 16.38 \\
\hline$(\mathrm{Sr} / \mathrm{Ce}) \mathrm{n}$ & 2.05 & 2.01 & 2.30 & 1.97 \\
\hline
\end{tabular}


1 Table 3. Compositions of LREE-depleted basalts from Hayyabley (average of the samples 2 analysed by ICP-MS), Manda Hararo (average data from Barrat et al., 2003), Ethiopian 3 Plateau (sample E88, Pik et al., 1999), and of a N-MORB from Tadjoura Gulf (sample A3D3, 4 Joron et al., 1980; Barrat et al., 1993). Major oxides in wt\%, trace elements in ppm. n denotes 5 ratios normalized to the primitive mantle composition from Sun and McDonough (1989). 6 
1 Table 4. $\mathrm{Sr}, \mathrm{Nd}$ and $\mathrm{Pb}$ isotopic compositions of Hayyabley basalts (B: bulk rock; R: residue 2 after leaching). See text for the analytical procedures. $\Delta 7 / 4$ and $\Delta 8 / 4$ denote the deviation (in $3{ }^{0} /{ }_{00}$ ) of ${ }^{207} \mathrm{~Pb} /{ }^{204} \mathrm{~Pb}$ and ${ }^{208} \mathrm{~Pb} /{ }^{204} \mathrm{~Pb}$ ratios with respect to the Northern Hemisphere Reference 4 Line (NHRL: Hart, 1984, 1988).

5

\begin{tabular}{lccccc}
\hline & DJ54B & DJ54H & DJ57 & DJ58 & DJ59 \\
& & & & & \\
${ }^{87} \mathrm{Sr} /{ }^{86} \mathrm{Sr}(\mathrm{B})$ & $0.703909 \pm 3$ & $0.703962 \pm 5$ & $0.703869 \pm 4$ & $0.703871 \pm 4$ & $0.703693 \pm 5$ \\
${ }^{87} \mathrm{Sr}{ }^{86} \mathrm{Sr}(\mathrm{R})$ & $0.703762 \pm 9$ & & & & \\
& & & & & \\
${ }^{143} \mathrm{Nd} /{ }^{144} \mathrm{Nd}(\mathrm{B})$ & $0.512961 \pm 4$ & $0.513001 \pm 3$ & $0.512965 \pm 4$ & $0.512942 \pm 3$ & $0.513010 \pm 4$ \\
$\varepsilon N \mathrm{Nd}$ & +6.3 & +7.1 & +6.4 & +5.9 & +7.3 \\
& & & & & \\
${ }^{206} \mathrm{~Pb} /{ }^{204} \mathrm{~Pb}(\mathrm{R})$ & $18.4856 \pm 15$ & $18.4776 \pm 15$ & $18.5502 \pm 27$ & $18.4842 \pm 17$ & $18.4979 \pm 21$ \\
${ }^{207} \mathrm{~Pb} /{ }^{204} \mathrm{~Pb}(\mathrm{R})$ & $15.5478 \pm 14$ & $15.5421 \pm 14$ & $15.5662 \pm 25$ & $15.5407 \pm 16$ & $15.5292 \pm 20$ \\
${ }^{208} \mathrm{~Pb} /{ }^{204} \mathrm{~Pb}(\mathrm{R})$ & $38.6917 \pm 43$ & $38.6658 \pm 44$ & $38.7692 \pm 78$ & $38.6217 \pm 50$ & $38.5842 \pm 61$ \\
$\Delta 7 / 4$ & 5.3 & 4.8 & 6.4 & 4.6 & 3.3 \\
${ }^{\Delta 8 / 4}$ & 71.6 & 69.9 & 71.5 & 64.7 & 59.3 \\
& & & & & \\
\hline
\end{tabular}

